\title{
Formation of secondary organic aerosol from isoprene oxidation over Europe
}

\author{
M. Karl ${ }^{1, *}$, K. Tsigaridis ${ }^{2}$, E. Vignati ${ }^{1}$, and F. Dentener ${ }^{1}$ \\ ${ }^{1}$ European Commission, Joint Research Centre, Institute for Environment and Sustainability, Ispra, Italy \\ ${ }^{2}$ NASA Goddard Institute for Space Studies, NY, USA \\ *now at: NILU, Norwegian Institute for Air Research, Kjeller, Norway
}

Received: 1 December 2008 - Published in Atmos. Chem. Phys. Discuss.: 29 January 2009

Revised: 11 August 2009 - Accepted: 27 August 2009 - Published: 22 September 2009

\begin{abstract}
The role of isoprene as a precursor to secondary organic aerosol (SOA) over Europe is studied with the twoway nested global chemistry transport model TM5. The inclusion of the formation of SOA from isoprene oxidation in our model almost doubles the atmospheric burden of SOA over Europe compared to SOA formation from terpenes and aromatics. The reference simulation, which considers SOA formation from isoprene, terpenes and aromatics, predicts a yearly European production rate of $1.0 \mathrm{Tg} \mathrm{SOA} \mathrm{yr}^{-1}$ and an annual averaged atmospheric burden of about $50 \mathrm{Gg}$ SOA over Europe. A fraction of $35 \%$ of the SOA produced in the boundary layer over Europe is transported to higher altitudes or to other world regions. Summertime measurements of organic matter (OM) during the extensive EMEP OC/EC campaign 2002/2003 are better reproduced when SOA formation from isoprene is taken into account, reflecting also the strong seasonality of isoprene and other biogenic volatile organic compounds (BVOC) emissions from vegetation. However, during winter, our model strongly underestimates OM, likely caused by missing wood burning in the emission inventories. Uncertainties in the parameterisation of isoprene SOA formation have been investigated. Maximum SOA production is found for irreversible sticking (non-equilibrium partitioning) of condensable vapours on particles, with tropospheric SOA production over Europe increased by a factor of 4 in summer compared to the reference case. Completely neglecting SOA formation from isoprene results in the lowest estimate

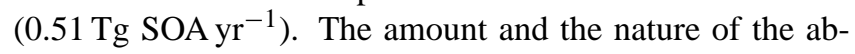

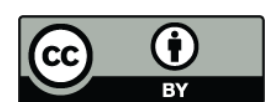

Correspondence to: F. Dentener (frank.dentener@jrc.it) sorbing matter are shown to be another key uncertainty when predicting SOA levels. Consequently, smog chamber experiments on SOA formation should be performed with different types of seed aerosols and without seed aerosols in order to derive an improved treatment of the absorption of SOA in the models. Consideration of a number of recent insights in isoprene SOA formation mechanisms reduces the tropospheric production of isoprene derived SOA over Europe from $0.4 \mathrm{Tg} \mathrm{yr}^{-1}$ in our reference simulation to $0.1 \mathrm{Tg} \mathrm{yr}^{-1}$.

\section{Introduction}

Global isoprene emissions are estimated to amount to approximately $250-750 \mathrm{TgC}^{-1}$, thus accounting for the majority of non-methane volatile organic compounds (NMVOC) emissions (Guenther et al., 1995, 2006). Smog chamber studies at ambient conditions suggest an important role of isoprene in atmospheric photochemistry (e.g. Karl et al., 2004, 2006). Although initial studies suggested that isoprene was not a significant precursor of SOA (Pandis, 1991), more recent laboratory and smog chamber studies (Edney et al., 2005; Kroll et al., 2005, 2006; Kleindienst et al., 2006) as well as field studies (Claeys et al., 2004a,b; Ion et al., 2005; Kourtchev et al., 2005; Matsunaga et al., 2005; Böge et al., 2006) clearly showed that isoprene can contribute significantly to the formation of secondary organic aerosol (SOA). There is however, controversy on the mechanisms and yields of SOA formation from isoprene.

In recent chamber studies a yield of $1-2 \%$ was found at high $\mathrm{NO}_{\mathrm{x}}\left(\left[\mathrm{NO}_{\mathrm{x}}\right]>75 \mathrm{ppbv}\right)$ conditions (Kroll et al., 2005) and about $3 \%$ at low $\mathrm{NO}_{\mathrm{x}}$ levels $\left(\left[\mathrm{NO}_{\mathrm{x}}\right]<1 \mathrm{ppbv}\right)$ (Kroll et

Published by Copernicus Publications on behalf of the European Geosciences Union. 
al., 2006). Based on measurements of isoprene oxidation products (2-methyltetrols) in aerosol samples, Claeys et al. (2004a) estimated a $0.4 \%$ SOA yield by mass from isoprene photo-oxidation. In contrast, Edney et al. (2005) found little evidence of isoprene-derived SOA formation in high atmospheric $\mathrm{NO}_{\mathrm{x}}$ conditions. However, when acidifying the aerosol seed, a SOA yield of $2.8 \%$ was observed, suggesting that acid-catalyzed reactions on acid aerosols are involved in the enhanced formation of SOA from isoprene. The formation of polymers has been invoked as a possible mechanism of SOA formation, either directly from isoprene (Limbeck et al., 2003) or from isoprene gas-phase oxidation products (Czoschke et al., 2003; Kleindienst et al., 2006; Surratt et al., 2006) via acid catalysis. Recent reaction chamber experiments indeed confirm the formation of polymers in isoprene oxidation experiments by reactive uptake into highly acidic sulphate aerosols (Liggio et al., 2007). Non-oxidative (accretion) reactions in the particle phase appear to be involved in the ageing of isoprene derived SOA. Dimeric hemiacetals and esters from isoprene oxidation have been found both in laboratory experiments and ambient aerosol (Surratt et al., 2006). Another important group of accretion reaction products formed from isoprene SOA seem to be organosulphates (Surratt et al., 2007a,b). Organosulphates from isoprene oxidation have also been detected at sites in Southeastern US and Europe (Surratt et al., 2007a; Gómez-González et al., 2008).

Recent work also suggests that in-cloud oxidation of water soluble isoprene oxidation products (in particular methylglyoxal and hydroxyacetaldehyde) can also produce SOA (Ervens et al., 2004). Lim et al. (2005) conclude that in-cloud oxidation of isoprene can yield SOA by up to $0.3 \%$ by mass. Calculations with CAPRAM 3.0i (Herrmann et al., 2005; Tilgner et al., 2008) confirmed earlier findings by Lim et al. (2005) showing that emissions of isoprene are linked to the in-cloud formation of oxalic acid via the formation of glycolaldehyde in the gas-phase oxidation of isoprene. Oxalic acid is one of the major identified single organic particle mass components. Model studies suggest that isoprene is the largest source of secondary produced glyoxal and methylglyoxal on the global scale (Saunders, 2003; Fu et al., 2008). New model results from Myriokefalitakis et al. (2008) underline the large global contribution of isoprene and other biogenic hydrocarbons to the water-soluble oxidation product glyoxal, and confirm overall agreement with satellite observations of this compound. Moreover, Fu et al. (2008) found that the global source of SOA by irreversible uptake of glyoxal and methylglyoxal may yield $11 \mathrm{Tg} \mathrm{yr}^{-1} \mathrm{SOA}$, with $90 \%$ of the formation taking place in clouds. Recent laboratory experiments have demonstrated the formation of higher molecular weight compounds, some with oligomeric structure, from the aqueous phase oxidation of pyruvic acid, glyoxal and methylglyoxal (Altieri et al., 2006, 2008; Carlton et al., 2007). Using a revised aqueous phase oxidation scheme for isoprene, including oligomer formation from glyoxal in the aqueous phase, Ervens et al. (2008) were able to predict in-cloud formation of glycolic, glyoxylic and oxalic acids in agreement with aircraft measurements of cloud-processed particles. They found that in regions with high $\mathrm{NO}_{\mathrm{x}}$ and isoprene emissions, together with abundant clouds, as it is the case in Northeastern US or Southeastern Asia, aqueous phase processed SOA might contribute significantly to total SOA.

Considering aqueous phase oxidation products from isoprene, Matsunaga et al. (2005) suggested a global annual production of $10-120 \mathrm{Tg}$ of organic aerosol matter from isoprene. In contrast, Claeys et al. (2004a) proposed that only a small fraction of all reacted isoprene is converted into SOA, corresponding to a source of $2 \mathrm{Tg} \mathrm{yr}^{-1}$ SOA. In perspective, a review by Kanakidou et al. (2005) suggested SOA formation from terpenes and other reactive VOC (ORVOC) emitted by the vegetation to range between 12 and $70 \mathrm{Tg} \mathrm{yr}^{-1}$. More recently much higher estimates of the biogenic SOA production have been inferred from top-down approaches. Based on the global mass-balance for atmospheric VOC, Goldstein and Galbally (2007) derived a global SOA production of up to $910 \mathrm{Tg} \mathrm{C} \mathrm{yr}^{-1}$. Their estimate has been further revised by Hallquist et al. (2009) who found that the total global flux of biogenic SOA could range between zero and $185 \mathrm{Tg} \mathrm{C} \mathrm{yr}^{-1}$, with a best estimate of $88 \mathrm{TgC} \mathrm{yr}^{-1}$. It should be noted that the top-down estimate by Hallquist et al. (2009) considers non-BVOC sources of SOA. Their approach considers VOC of intermediate volatility (IVOC), with saturation concentrations between $10^{3}$ and $10^{6} \mathrm{\mu g} \mathrm{m}^{-3}$, emitted during biomass burning which may partition to the primary organic aerosol (POA), and the oxidation of low volatility VOC to create oxidized primary aerosol (Robinson et al., 2007; Donahue et al., 2009). In the present study, direct emissions of IVOC or semi-volatile vapours are not included. In our work, we focus on SOA production in terms of "traditional" SOA, originating from the photo-oxidation of individual VOC like isoprene, terpenes, and aromatics. Thus our results should be seen in context of the range provided by Kanakidou et al. (2005).

A global model study by Henze and Seinfeld (2006) evaluated the formation of SOA from isoprene oxidation based on laboratory chamber data from Kroll et al. (2006), suggesting that photo-oxidation of isoprene and consequent SOA formation may contribute $6 \mathrm{Tg} \mathrm{yr}^{-1}$, or $47 \%$ of their total predicted SOA production, equal to roughly a doubling of the simulated SOA burden obtained from terpene oxidation alone. Using the same SOA yields, a regional model study by Liao et al. (2007) suggested that isoprene oxidation contributed 50\% to SOA concentrations over the USA and 58\% to the global SOA concentrations for the years 2001-2003. Assuming a fixed 2\% SOA mass yield from isoprene oxidation, van Donkelaar et al. (2007) was able to improve the comparison of modelled and measured organic aerosol (OA) surface mass in the USA. According to present-day model simulations of Tsigaridis and Kanakidou (2007), isoprene oxidation produces $4.6 \mathrm{Tg} \mathrm{SOA} \mathrm{yr}^{-1}$ with the two-product 
approach from Henze and Seinfeld on a global scale, which corresponds to $38 \%$ of the $12.2 \mathrm{Tg} \mathrm{SOA} \mathrm{yr}^{-1}$ formed by the oxidation of other BVOC and to $27 \%$ of the total SOA in their simulations.

Tsigaridis and Kanakidou (2003) presented a comprehensive sensitivity study on SOA formation on a global scale using a previous version (TM3) of the model used in this work. They found that the global annual SOA production from biogenic volatile organic compounds (VOC) ranges between 2.5 and $44.5 \mathrm{Tg}$ and from anthropogenic VOC (aromatics) ranges between $0.05 \mathrm{Tg}$ and $2.62 \mathrm{Tg}$. The given ranges reflect the uncertainties in the treatment of SOA formation. However, formation of SOA from isoprene was not included in that study.

A long array of uncertainties is associated with the formation of secondary organic aerosols (Kanakidou et al., 2005), beginning with the emissions of the volatile organic compounds (VOC) that act as precursors of SOA, followed by the formation processes of semi volatile organic gases and their condensation on pre-existing aerosols and finally the effectiveness of removal of SOA from the atmosphere, mainly by wet deposition. Currently identified major uncertainties that influence the yields of SOA from isoprene and monoterpenes are the levels of ambient $\mathrm{NO}_{\mathrm{x}}$ concentrations or $\mathrm{VOC} / \mathrm{NO}_{\mathrm{x}}$ ratios (Presto et al., 2005b; Presto and Donahue, 2006; Kroll et al., 2006), the temperature dependence of the partitioning coefficient (Offenberg et al., 2006), relative humidity (Jang and Kamens, 1998; Cocker et al., 2001), the role of acid-catalyzed heterogeneous reactions of carbonyl products (Czoschke et al., 2003; Iinuma et al., 2004; Czoschke and Jang, 2006), the possible formation of high molecular weight products (oligomers, humic like substances) (Kalberer et al., 2006; Surratt et al., 2006; Heaton et al., 2007), the role of sulphate aerosol concentration in the condensation process (Kleindienst et al., 2006; Kroll et al., 2007), the effect of UV-light (Presto et al., 2005a), and the absorption properties of pre-existing carbonaceous particulate matter (e.g. Seinfeld and Pankow, 2003). Furthermore, the importance of isoprene as a precursor of SOA is determined not only by SOA yields but also by the total amount of isoprene emissions from vegetation (Carlton et al., 2009).

In this work we use the global atmospheric transport model TM5, with a $1^{\circ} \times 1^{\circ}$ resolution over the European domain to study SOA formation over Europe. We build up on the previous sensitivity analysis on global SOA performed by Tsigaridis and Kanakidou (2003) and further expand their approach by focusing on the role of isoprene in the formation of secondary organic aerosol over Europe on a high spatial and temporal resolution. This work integrates the most recent insights on isoprene SOA formation in TM5 and we perform a number of simulations to investigate the sensitivity of our model results to different European isoprene emissions inventories, different representations of the isoprene SOA formation route, and assumptions regarding the effectiveness of wet removal of isoprene oxidation products. To place the previously mentioned simulations in context of prior studies, we repeat some sensitivity studies already presented in Tsigaridis and Kanakidou (2003). Moreover, we assess to what extend the new results can be reconciled with particulate organic matter observations from the EMEP OC/EC campaign in 2002-2003 (Yttri et al., 2007).

\section{Model description}

\subsection{Atmospheric transport model TM5}

In this work, the two-way nested atmospheric zoom model TM5 is used. The TM5 model is an off-line global chemistry/transport model (Krol et al., 2005) that uses meteorological fields, including large-scale and convective precipitation and cloud data, from the European Centre for Medium Range Weather Forecast (ECMWF). The standard version of TM5 employs 25 vertical layers which are derived from the 60 layers of the operational ECMWF model. Since the focus is on the troposphere, higher vertical resolution is maintained in the boundary layer and in the free troposphere. Globally, a horizontal resolution of $6^{\circ} \times 4^{\circ}$ (longitude $\times$ latitude) is employed. The two-way zooming algorithm allows resolving the European domain $\left(18^{\circ} \mathrm{W}, 14^{\circ} \mathrm{N}\right.$ to $\left.36^{\circ} \mathrm{E}, 64^{\circ} \mathrm{N}\right)$ with a finer resolution of $1^{\circ} \times 1^{\circ}$. To smooth the transition between the global $6^{\circ} \times 4^{\circ}$ region and the regional $1^{\circ} \times 1^{\circ}$ domain, a domain with a $3^{\circ} \times 2^{\circ}$ area resolution has been added, stretching from $32^{\circ} \mathrm{W}, 4^{\circ} \mathrm{N}$ to $51^{\circ} \mathrm{E}, 72^{\circ} \mathrm{N}$.

The slopes advection scheme (Russel and Lerner, 1981) has been implemented; non-resolved transport by deep and shallow cumulus convection is parameterised according to Tiedtke (1989). The vertical diffusion parameterisation of Holtslag and Moeng (1991) is used for near surface mixing. In the free troposphere, the formulation of Louis (1979) is used. The model transport has been extensively validated using ${ }^{222} \mathrm{Rn}$ and $\mathrm{SF}_{6}$ (Peters et al., 2004; Krol et al., 2005) and also within the EVERGREEN project (Bergamaschi et al., 2006).

\subsection{Gas-phase chemistry}

The gas phase chemistry is calculated using the CBM-IV chemical mechanism (lumped structure approach; Gery et al., 1989a, b) as modified by Houweling et al. (1998), solved by means of the Eulerean backward iterative (EBI) method (Hertel et al., 1993). In this version of the TM5 model the coupled aerosol module to calculate secondary organic aerosols developed by Tsigaridis et al. (2006) is applied and has been appropriately linked to the gas phase chemical mechanism. To this purpose, CBM-IV was modified accordingly to include the gas phase precursors of SOA, i.e. $\alpha$ pinene, $\beta$-pinene, toluene, xylene, $\beta$-caryophyllene which have not been considered previously, the reactions and rate constants of these VOCs with atmospheric oxidants are listed in Table 1. Biogenic volatile organic compounds (BVOC) 
Table 1. Reactions of SOA-precursor VOC with atmospheric oxidants included in TM5 (reactions with gas-phase products and temperature dependent rate constants).

\begin{tabular}{|c|c|c|c|}
\hline \multicolumn{3}{|c|}{ VOC+Oxidant reaction } & \multirow{2}{*}{$\begin{array}{l}\text { Rate constant } \\
2.54 \times 10^{-11} \exp (410 / T)\end{array}$} \\
\hline $\mathrm{ISOP}+\mathrm{OH}$ & $\rightarrow$ & $0.61 \mathrm{HCHO}+0.03 \mathrm{MGLY}+0.58 \mathrm{OLE}+0.63 \mathrm{PAR}+0.85 \mathrm{HO}_{2}+0.85 \mathrm{XO}_{2}+0.15 \mathrm{XO}_{2} \mathrm{~N}$ & \\
\hline $\mathrm{ISOP}+\mathrm{O}_{3}$ & $\rightarrow$ & $0.90 \mathrm{HCHO}+0.03 \mathrm{MGLY}+0.55 \mathrm{OLE}+0.36 \mathrm{CO}+0.63 \mathrm{PAR}+0.15 \mathrm{C}_{2} \mathrm{O}_{3}$ & \\
\hline & & $+0.28 \mathrm{OH}+0.30 \mathrm{HO}_{2}+0.18 \mathrm{XO}_{2}$ & $12.3 \times 10^{-15} \exp (-2013 / T)$ \\
\hline $\mathrm{ISOP}+\mathrm{NO}_{3}$ & $\rightarrow$ & $0.03 \mathrm{HCHO}+0.12 \mathrm{ALD} 2+0.08 \mathrm{MGLY}+0.45 \mathrm{OLE}+0.90 \mathrm{ORGNTR}+0.90 \mathrm{HO}_{2}+0.10 \mathrm{NO}_{2}$ & $7.8 \times 10^{-13}=$ \\
\hline $\mathrm{APIN}+\mathrm{OH}$ & $\rightarrow$ & $1.22 \mathrm{HCHO}+0.06 \mathrm{MGLY}+1.16 \mathrm{OLE}+1.26 \mathrm{PAR}+1.70 \mathrm{HO}_{2}+0.15 \mathrm{XO}_{2} \mathrm{~N}+0.70 \mathrm{TERO}_{2}$ & $1.21 \times 10^{-11} \exp (444 / T)$ \\
\hline $\mathrm{APIN}+\mathrm{O}_{3}$ & $\rightarrow$ & $1.80 \mathrm{HCHO}+0.06 \mathrm{MGLY}+0.72 \mathrm{CO}+1.26 \mathrm{PAR}+0.46 \mathrm{OH}+0.60 \mathrm{HO}_{2}+1.00 \mathrm{TERO}_{2}$ & $1.01 \times 10^{-15} \exp (-732 / T)$ \\
\hline $\mathrm{APIN}+\mathrm{NO}_{3}$ & $\rightarrow$ & $0.06 \mathrm{HCHO}+0.24 \mathrm{ALD} 2+0.16 \mathrm{MGLY}+0.90 \mathrm{OLE}+1.80 \mathrm{ORGNTR}+1.80 \mathrm{HO}_{2}+0.20 \mathrm{NO}_{2}$ & $3.15 \times 10^{-13} \exp (841 / T)$ \\
\hline $\mathrm{BPIN}+\mathrm{OH}$ & $\rightarrow$ & $1.22 \mathrm{HCHO}+0.06 \mathrm{MGLY}+1.16 \mathrm{OLE}+1.26 \mathrm{PAR}+1.70 \mathrm{HO}_{2}+0.15 \mathrm{XO}_{2} \mathrm{~N}+0.70 \mathrm{TERO}_{2}$ & $2.38 \times 10^{-11} \exp (357 / T)$ \\
\hline $\mathrm{BPIN}+\mathrm{O}_{3}$ & $\rightarrow$ & $1.80 \mathrm{HCHO}+0.06 \mathrm{MGLY}+0.72 \mathrm{CO}+1.26 \mathrm{PAR}+0.46 \mathrm{OH}+0.60 \mathrm{HO}_{2}+1.00 \mathrm{TERO}_{2}$ & $1.5 \times 10^{-17}-2$ \\
\hline $\mathrm{BPIN}+\mathrm{NO}_{3}$ & $\rightarrow$ & $0.06 \mathrm{HCHO}+0.24 \mathrm{ALD} 2+0.16 \mathrm{MGLY}+0.90 \mathrm{OLE}+1.80 \mathrm{ORGNTR}+1.00 \mathrm{CO}$ & \\
\hline & & $+1.80 \mathrm{HO}_{2}+0.20 \mathrm{NO}_{2}$ & $1.6 \times 10^{-10} \exp (-1248 / T)$ \\
\hline $\mathrm{BCAR}+\mathrm{OH}$ & $\rightarrow$ & $2.00 \mathrm{HO}_{2}$ & $20.0 \times 10^{-11}$ \\
\hline $\mathrm{BCAR}+\mathrm{O}_{3}$ & $\rightarrow$ & $1.60 \mathrm{HCHO}+0.40 \mathrm{ROOH}+0.12 \mathrm{OH}$ & $11.6 \times 10^{-15}$ \\
\hline $\mathrm{BCAR}+\mathrm{NO}_{3}$ & $\rightarrow$ & $0.06 \mathrm{HCHO}+0.24 \mathrm{ALD} 2+0.16 \mathrm{MGLY}+0.90 \mathrm{OLE}+1.80 \mathrm{ORGNTR}+1.80 \mathrm{HO}_{2}+0.20 \mathrm{NO}_{2}$ & $1.9 \times 10^{-11}$ \\
\hline $\mathrm{TOL}+\mathrm{OH}$ & $\rightarrow$ & 7.00 $\mathrm{PAR}+1.00 \mathrm{AROO}_{2}$ & $5.96 \times 10^{-12}$ \\
\hline $\mathrm{TOL}+\mathrm{O}_{3}$ & $\rightarrow$ & 8.00 PAR + 1.00 $\mathrm{AROO}_{2}$ & $2.34 \times 10^{-12} \exp (-6694 / T)$ \\
\hline $\mathrm{TOL}+\mathrm{NO}_{3}$ & $\rightarrow$ & 1.00 MGLY & $6.8 \times 10^{-17}$ \\
\hline $\mathrm{XYL}+\mathrm{OH}$ & $\rightarrow$ & 7.00 $\mathrm{PAR}+1.00 \mathrm{AROO}_{2}$ & $\left(1.37 \times 10^{-11}+2.36 \times 10^{-11}+1.43 \times 10^{-11}\right) / 3^{\mathrm{a}}$ \\
\hline $\mathrm{XYL}+\mathrm{O}_{3}$ & $\rightarrow$ & 8.00 PAR + $1.00 \mathrm{AROO}_{2}$ & \\
\hline $\mathrm{XYL}+\mathrm{NO}_{3}$ & $\rightarrow$ & $1.00 \mathrm{MGLY}+1.00 \mathrm{PAR}$ & $\left(3.8 \times 10^{-16}+2.33 \times 10^{-16}+4.5 \times 10^{-16}\right) / 3^{a}$ \\
\hline \multicolumn{4}{|c|}{ Reactions of organic peroxy radicals and operator species } \\
\hline $\mathrm{TERO}_{2}+\mathrm{NO}$ & $\rightarrow$ & $\mathrm{NO}_{2}$ & $4.2 \times 10^{-12} \exp (180 / T)$ \\
\hline $\mathrm{TERO}_{2}+\mathrm{TERO}_{2}$ & $\rightarrow$ & & $1.7 \times 10^{-14} \exp (1300 / T)$ \\
\hline $\mathrm{TERO}_{2}+\mathrm{HO}_{2}$ & $\rightarrow$ & $\mathrm{ROOH}$ & $3.5 \times 10^{-13} \exp (1000 / T)$ \\
\hline $\mathrm{TERO}_{2}+\mathrm{XO}_{2}$ & $\rightarrow$ & & $1.7 \times 10^{-14} \exp (1300 / T)$ \\
\hline $\mathrm{TERO}_{2}+\mathrm{AROO}_{2}$ & $\rightarrow$ & & $1.7 \times 10^{-14} \exp (1300 / T)$ \\
\hline $\mathrm{AROO}_{2}+\mathrm{NO}$ & $\rightarrow$ & $\mathrm{NO}_{2}$ & $4.2 \times 10^{-12} \exp (180 / T)$ \\
\hline $\mathrm{AROO}_{2}+\mathrm{AROO}_{2}$ & $\rightarrow$ & & $1.7 \times 10^{-14} \exp (1300 / T)$ \\
\hline $\mathrm{AROO}_{2}+\mathrm{HO}_{2}$ & $\rightarrow$ & $\mathrm{ROOH}$ & $3.5 \times 10^{-13} \exp (1000 / T)$ \\
\hline $\mathrm{AROO}_{2}+\mathrm{XO}_{2}$ & $\rightarrow$ & & $1.7 \times 10^{-14} \exp (1300 / T)$ \\
\hline $\mathrm{XO}_{2}+\mathrm{NO}$ & $\rightarrow$ & $\mathrm{NO}_{2}$ & $4.2 \times 10^{-12} \exp (180 / T)$ \\
\hline $\mathrm{XO}_{2}+\mathrm{XO}_{2}$ & $\rightarrow$ & & $1.7 \times 10^{-14} \exp (1300 / T)$ \\
\hline $\mathrm{XO}_{2}+\mathrm{HO}_{2}$ & $\rightarrow$ & $\mathrm{ROOH}$ & $3.5 \times 10^{-13} \exp (1000 / T)$ \\
\hline $\mathrm{XO}_{2} \mathrm{~N}+\mathrm{NO}$ & $\rightarrow$ & ORGNIT & $6.8 \times 10^{-13}$ \\
\hline $\mathrm{XO}_{2} \mathrm{~N}+\mathrm{HO}_{2}$ & $\rightarrow$ & $\mathrm{ROOH}$ & c \\
\hline
\end{tabular}

a Average of rate constant of the ortho-, meta-, and para-isomers.

$\mathrm{b}$ Average of temperature dependent rate constants of the ortho-, meta-, and para-isomers: $\left(2.4 \times 10^{-13} \exp (-5586 / T)+5.37 \times 10^{-13} \exp (-6039 / T)+1.91 \times 10^{-13} \exp (-5586 / T)\right) / 3$.

${ }^{\mathrm{c}}\left[6.8 \times 10^{-13} \times\left(3.5 \times 10^{-13} \exp (1000 / T)\right)\right] /\left[4.2 \times 10^{-12} \exp (180 / T)\right]$.

that form SOA like monoterpenes and other reactive volatile organic compounds (ORVOC) are represented by $\alpha$-pinene and $\beta$-pinene. Toluene and xylene represent the anthropogenically emitted aromatic compounds that form SOA. New in this work compared to Tsigaridis et al. (2006) is the consideration of isoprene and sesquiterpenes, the latter represented by $\beta$-caryophyllene, as additional biogenic SOA precursors. The standard parameterisation of SOA formation in TM5 corresponds to the scenario S1.1 given in Tsigaridis and Kanakidou (2003) (see Sect. 2.5).

\subsection{NMVOC emissions}

SOA is formed in the gas-phase oxidation of biogenic and anthropogenic NMVOC in the atmosphere. The global production is estimated to range from $12-70 \mathrm{Tg} \mathrm{yr}^{-1}$ SOA with a central estimate of about $30 \mathrm{Tg} \mathrm{yr}^{-1}$ SOA (PHOENICS Synthesis and Integration Report, 2005; Kanakidou et al.,
2005). The largest fraction of SOA is from biogenic precursors while the anthropogenic SOA production is roughly a factor of 10 smaller. As stated in the introduction, the given range refers to production in terms of "traditional" SOA and the formation of SOA as a result of the multi-step oxidation of directly emitted compounds with intermediate volatility from biomass burning or diesel exhaust might be larger.

Anthropogenic emissions of non-aromatic NMVOC are implemented and distributed among CBM-IV compounds as described in Houweling et al. (1998). The terrestrial biosphere is a major source of BVOC. According to the Global Emission Inventory Activity (GEIA) database (Guenther et al., 1995) about $503 \mathrm{Tg} \mathrm{C}$ of isoprene, $127 \mathrm{Tg} \mathrm{C}$ of monoterpenes, and $260 \mathrm{Tg} \mathrm{C}$ ORVOC are emitted annually into the atmosphere. Monthly BVOC emissions calculated in our reference simulation (see description below) correspond to monthly emission fluxes from the GEIA database (Guenther 
et al., 1995). BVOC emissions from the GEIA inventory are based on the year 1990. We note that there are more recent estimates for BVOC emissions on the global scale (Lathière et al., 2005; Guenther et al., 2006) and European scale (Karl et al., 2009; Steinbrecher et al., 2009). The GEIA emission database has been chosen to allow for maximum consistency with earlier TM5 versions, while the more recent emission estimates are used in the present study to estimate the sensitivity of SOA formation to emissions.

ORVOC are defined as compounds with a lifetime under typical tropospheric conditions of less than 1 day (Guenther et al., 1995). Griffin et al. (1999b) have determined the contribution of individual chemical compounds to the emissions of ORVOC on a global scale based on the emissions from predominant plant species. According to these authors, 32\% of the total ORVOC emissions contribute to SOA formation. Following Griffin et al. (1999b), we assume that $5 \%$ of the emissions of ORVOC are sesquiterpenes, represented by $\beta$ caryophyllene. Among the remaining ORVOC constituents that contribute to the formation of SOA, $48 \%$ have a terpenoid molecule structure, while $52 \%$ have an aliphatic (C7C9 n-carbonyls, higher olefins) or aromatic structure. For simplicity, $\beta$-pinene was used to represent the less effective aliphatic and aromatic fraction of the SOA-forming ORVOC compounds, while $\alpha$-pinene was used to represent the more efficient terpenoids. Consequently, the remaining ORVOC emissions are distributed equally between $\alpha$ - and $\beta$-pinene. Emissions of monoterpenes and ORVOC are assumed to depend only on temperature, while isoprene emissions depend on temperature and light (e.g. Tingey et al., 1991; Guenther et al., 1993). The equations describing the dependence of isoprene emissions on temperature and light and the dependence of terpene and ORVOC emissions on temperature given by Guenther (1997) are applied.

Together with the global fields of emission factors and foliar biomass densities, BVOC emissions at any location and time during the simulation are calculated on-line. Emission factors and foliar biomass densities have been compiled as described in Guenther et al. (1995) for 72 ecosystem classes defined by Olson (1992). The BVOC emission module applies the radiation code of Weiss and Norman (1985) to calculate the extinction of light as a function of the leaf area index (LAI), the distribution of the LAI inside the canopy (leaf area density), the fraction of leaves and the orientation of these leaves. Applying this BVOC emission module in TM5 with ECMWF meteorological data results in global isoprene emissions of about $500 \mathrm{Tg} \mathrm{yr}^{-1}$.

Apart from BVOC, aromatic compounds have the potential to form secondary organic aerosols (Odum et al., 1997). The emissions of aromatic hydrocarbons are adopted from the Emission Database for Global Atmospheric Research (EDGAR) version 2.0 (Olivier et al., 1996) for the year 1990. Unfortunately there is no more recent speciated VOC emission database covering our model domain available. These emissions add up to about $10-15 \%$ of all anthropogenic
NMVOC emissions. Emissions of aromatics from biofuel and biomass burning are not considered at the moment as they are highly uncertain over Europe. In Europe and USA decreasing trends of aromatic hydrocarbon emissions have been reported in the last 2-3 decades (EMEP, 2008; US EPA, 2008). The relatively crude estimate of emissions of aromatic compounds in our model study can be justified by the small relative contribution of aromatic hydrocarbons to the total SOA production.

\subsection{Primary and inorganic aerosols}

Gas phase chemistry (Sect. 2.2) and secondary aerosol formation are coupled and computed online together with all other aerosol compounds in this version of TM5. Sulphate is assumed to be present only in the aerosol phase. It is formed by the oxidation of $\mathrm{SO}_{2}$ (and DMS) in the gas phase by $\mathrm{OH}$ and in the aqueous phase by $\mathrm{H}_{2} \mathrm{O}_{2}$ and $\mathrm{O}_{3}$. Black carbon (BC) and primary organic carbon (POC) are, as well as inorganic components, considered externally mixed; they are described only by mass, and being in the accumulation mode with a mass mean radius of $0.14 \mu \mathrm{m}$ for wet and dry removal processes. Sea salt and dust are externally mixed components in the model; they are described by lognormal distributions (Aitken, accumulation and coarse mode for sea salt and accumulation and coarse mode for dust). The equilibrium model EQSAM2 (Metzger et al., 2002a, b) is used to calculate the partitioning between the aerosol and gas phases of ammonia, nitric acid, ammonium and nitrate and the water attached to the particle in equilibrium with the water vapour (Vignati et al., 2005). In-cloud as well as below-cloud wet removal are parameterized differently for convective and stratiform precipitation, building on the work of Guelle et al. (1998) and Jeuken et al. (2001). Sedimentation is only taken into account for the coarse mode of dust and sea salt particles.

The global emission inventories of primary carbonaceous particles (black carbon and primary organic carbon) used in the present work are from Bond et al. (2004) for the anthropogenic contributions (fossil and biofuels) and from van der Werf et al. (2004) for the large scale biomass burning areas. Anthropogenic emissions are given with an uncertainty factor of two (Bond et al., 2004). We assume that $100 \%$ of the emitted black carbon and $35 \%$ of the emitted primary organic carbon are hydrophobic (Cooke and Wilson, 1996; MayolBracero et al., 2002). The conversion of BC and POC from hydrophobic to hydrophilic is assumed to occur by reaction with ozone and follows the description given in Tsigaridis and Kanakidou (2003). The chemical ageing process thus depends on $\mathrm{O}_{3}$ levels and ambient humidity and has a strong effect on the removal of carbonaceous aerosols, since hydrophilic BC and POC are more efficiently scavenged in clouds than hydrophobic BC and POC. We note that there are also other parameterisations of aerosol-ageing; it was beyond the scope of this paper to explore these. 
Secondary organic aerosol particles are assumed to be hydrophilic. In clouds, $30 \%$ of the mass of hydrophilic BC, hydrophilic POC and SOA remain in the interstitial air of clouds, while $70 \%$ behave as hygroscopic and thus undergo wet deposition by in-cloud and below-cloud scavenging. Hydrophobic aerosols are not removed by in-cloud scavenging. Wet removal of SOA is in rough agreement with Chung and Seinfeld (2002) who assume $20 \%$ of the SOA mass to be hydrophobic. Gases are scavenged according to their solubility. The dry deposition of gases and aerosols is calculated using the ECMWF surface characteristics and the resistance method (Ganzeveld and Lelieveld, 1995).

De Meij et al. (2006) compared European aerosol optical depth (AOD) calculated with TM5 using the EMEP emission inventory (containing $\mathrm{SO}_{2}, \mathrm{NO}_{\mathrm{x}}, \mathrm{NH}_{3}, \mathrm{PM}_{2.5}, \mathrm{PM}_{\text {coarse }}$ ) and the AEROCOM inventory (containing $\mathrm{SO}_{2}$, particulate organic matter, BC; Dentener et al., 2006) with surface data from AERONET observation sites and with MODIS satellite data. Calculated AOD with both inventories underestimated the observed AERONET AOD values by $20-30 \%$ but show good spatial agreement with MODIS data. In the case of the AEROCOM inventory, a simplified global SOA source yielding $19.1 \mathrm{Tg} \mathrm{yr}^{-1}$ (Europe: $0.41 \mathrm{Tg} \mathrm{yr}^{-1}$ ) particulate organic matter had been applied based on the assumption that $15 \%$ of natural terpene emissions form non-volatile SOA instantaneously when emitted.

\subsection{Formation of secondary organic aerosols}

We parameterize the formation of SOA using a two-product model approximation. Each precursor VOC reacts with atmospheric oxidants to produce two surrogate compounds (of different volatility) that can partition to the aerosol phase. An equilibrium partitioning into an absorptive organic matter phase (Black Carbon and Primary Organic Carbon) according to the concept proposed originally by Pankow (1994a, b) and Odum et al. (1996) and further refined by Tsigaridis and Kanakidou (2003) is used in this work. Heterogeneous and aqueous phase reactions forming SOA are not included in the current model since the level of understanding is still low. In view of the complex nature of SOA formation with respect to oxidative and non-oxidative reactions in the particulate phase (e.g. Kroll and Seinfeld, 2008 and references therein) and the multigenerational processing of vapours in both the gas and particle phase during their transport in the atmosphere (Robinson et al., 2007), the limitations of the traditional two-product model applied in this study are obvious. One possibility to overcome the current limitations could be an extension of the two product approach to a 4+1P model by including one product that is more volatile and one that is less volatile than the two products used in the traditional model, and one polymer compound (Pankow and Barsanti, 2009). Donahue et al. (2006) proposed to represent the partitioning of organics by using fixed logarithmically spaced saturation concentration bins, the "volatility basis set" (VBS). The lower and upper ends of the volatility range (typically from $0.01 \mu \mathrm{g} \mathrm{m}^{-3}$ to $10^{6} \mu \mathrm{g} \mathrm{m}^{-3}$ at $298 \mathrm{~K}$ ) are selected to cover the range of atmospheric conditions. Chemical ageing and multigenerational processing in the gas phase and condensed phase can be captured in the VBS by simply redistributing material from one volatility bin to another. For more details on this approach we refer the reader to the work of Donahue and co-workers (Donahue et al., 2006, 2009; Presto and Donahue, 2006; Pathak et al., 2007).

The partitioning of a condensable compound $i$ between the gas phase and the aerosol phase is described by the gas/particle partitioning coefficient $K_{p, i}$ for absorptive uptake into the particle phase (Pankow, 1994a; Seinfeld and Pankow, 2003; Pankow and Barsanti, 2009):

$K_{p, i}=\frac{A_{i}}{G_{i} M_{t}}=\frac{10^{-6} R T f}{M W \zeta_{i} p_{L, i}^{0}}$

Where $p_{L, i}^{0}$ is the pure compound's vapour pressure in atm, $T$ is temperature in $\mathrm{K}, G_{i}\left(\mathrm{ng} \mathrm{m}^{-3}\right)$ is the concentration in the gas phase, $A_{i}\left(\mathrm{ng} \mathrm{m}^{-3}\right)$ is the concentration in the (largely organic) material aerosol phase, $R$ is the universal gas constant $\left(8.206 \times 10^{-5} \mathrm{~m}^{3} \mathrm{~atm} \mathrm{~mol}{ }^{-1} \mathrm{~K}^{-1}\right), f$ is the absorptive mass fraction, $\zeta_{i}$ is the activity coefficient of compound $i$ in that particulate phase, and $10^{-6}$ is a conversion factor $(\mathrm{g} / \mu \mathrm{g})$. The activity coefficient $\zeta_{i}$ describes the non-ideal interaction between the dissolved species $i$ and the other components of the (organic) particulate phase. Note that Eq. (1) is entirely general and applies to partitioning to any condensed phase, including those that contain inorganic species (Pankow and Barsanti, 2009). $M_{t}$ is the total mass concentration of the absorbing phase (in $\left.\mu \mathrm{g} \mathrm{m}^{-3}\right) . M W(\mathrm{~g} / \mathrm{mol})$ is the average molecular weight of the absorbing phase:

$M W=\sum_{i} x_{i} M W_{i}$

It is calculated as a weighted average of the mixture component molecular weights, $M W_{i}$, using the aerosol phase mole fraction $x_{i}$.

Monoterpenes, represented by the model compounds $\alpha$ pinene and $\beta$-pinene, are known to react rapidly with $\mathrm{OH}$, $\mathrm{O}_{3}$ and $\mathrm{NO}_{3}$. During night time, the reaction of $\mathrm{NO}_{3}$ with monoterpenes is expected to be the predominant gas-phase loss pathway for monoterpenes. In our SOA representation, only the reactions with $\mathrm{OH}$ and $\mathrm{O}_{3}$ are considered to lead to SOA production. We did not include possible SOA formation from the reaction of $\alpha$-pinene and $\beta$-pinene with $\mathrm{NO}_{3}$, because recent measurements suggest a minor role of this oxidation route for SOA. Though Spittler et al. (2006) found the SOA yield to be $16 \%$ for the reaction of $\alpha$-pinene with $\mathrm{NO}_{3}$ under dry conditions, it was only $4 \%$ under humid conditions. In atmospheric simulations aerosol formation from the $\mathrm{NO}_{3}$ reaction with $\alpha$-pinene is found to be negligible compared to the large contributions from ozonolysis and from the OH reaction (Griffin et al., 1999a; Capouet et al., 2008). 
Table 2. Properties of SOA compounds used by the two-product approach that have been introduced in this work: mass based stoichiometric coefficient $(\alpha)$, equilibrium gas-particle partitioning coefficient $\left(K_{p}\right)$, and enthalpy of vaporisation $\left(\Delta H_{\mathrm{vap}}\right)$.

\begin{tabular}{|c|c|c|c|c|c|}
\hline Parent VOC & SOA product & $\begin{array}{l}\alpha_{i} \\
\text { (mass-based) }\end{array}$ & $\begin{array}{l}K_{p, i} \\
\left(\mathrm{~m}^{3} \mu \mathrm{g}^{-1}\right)\end{array}$ & $\begin{array}{l}\Delta H_{\text {vap }, i} \\
\left(\mathrm{~kJ} \mathrm{~mol}^{-1}\right)\end{array}$ & Reference \\
\hline isoprene & ISOPp1 & 0.232 & 0.00862 & 42 & Henze and Seinfeld (2006) \\
\hline isoprene & ISOPp2 & 0.0288 & 1.62 & 42 & Henze and Seinfeld (2006) \\
\hline$\beta$-caryophyllene & BCARp1 & 0.20 & 0.05 & $72.7^{\mathrm{a}}$ & Hoffmann et al. (1997) \\
\hline$\beta$-caryophyllene & BCARp $2^{b}$ & 0.80 & $1.0 \times 10^{-5}$ & $72.7^{\mathrm{a}}$ & Hoffmann et al. (1997) \\
\hline
\end{tabular}

a recommended value from Pun et al. (2003).

${ }^{\mathrm{b}} \mathrm{BCARp} 2$ is further oxidised by $\mathrm{OH}, \mathrm{O}_{3}$ and $\mathrm{NO}_{3}$ to give a non-volatile SOA compound.

The on-line modelled parameters that determine the formation of SOA are precursor concentrations, oxidant fields, pre-existing mass of carbonaceous aerosol and temperature. Information on reaction rate constants with ozone and hydroxyl radical, aerosol yields and partitioning coefficients for $\alpha$-pinene, $\beta$-pinene, toluene and xylene are adopted from Tsigaridis and Kanakidou (2003). Isoprene SOA formation is implemented according to the recommendations of Henze and Seinfeld (2006). This is new compared to the work of Tsigaridis et al. (2006) who applied a fixed molar aerosol yield from isoprene oxidation of $0.2 \%$ based on Claeys et al. (2004a). Recent laboratory experiments of Kleindienst et al. (2007a) showed that SOA formation from isoprene is dominated by the $\mathrm{OH}$-initiated oxidation. In TM5 global scale calculations, $\mathrm{OH}$ is responsible for $86 \%$ of the oxidation of isoprene, while $\mathrm{O}_{3}$ and $\mathrm{NO}_{3}$ account for only $11 \%$ and $3 \%$ of the isoprene oxidation, respectively. Though formation of SOA during the oxidation of isoprene with $\mathrm{O}_{3}$ or $\mathrm{NO}_{3}$ may also occur, this will be important only during night time, when $\mathrm{OH}$ is vanished. Due to the light-dependence there are no isoprene emissions during night and thus sources of isoprene-derived SOA other than the $\mathrm{OH}$ reaction can be neglected. Therefore, in accordance with Henze and Seinfeld (2006), we assume that the reaction of isoprene with $\mathrm{OH}$ is the only pathway for formation of SOA from isoprene in the atmosphere.

Sesquiterpenes are treated as separate SOA precursors. In contrast to the ozonolysis of $\alpha$-pinene which produces only first-generation products, the ozonolysis of $\beta$-caryophyllene and other sesquiterpenes leads to a substantial growth of organic matter, even after the complete consumption of the parent hydrocarbon, indicating that the formation of secondgeneration products is important in determining the overall aerosol yield ( $\mathrm{Ng}$ et al., 2006). The possibility to form second-generation products seems to be related to the oxidation of the second carbon double bond of the sesquiterpene molecule. Following the formation mechanism originally proposed by Hoffmann et al. (1997), a 100\% yield of semivolatile gas phase products is obtained from the oxidation of $\beta$-caryophyllene with $\mathrm{OH}$ and $\mathrm{O}_{3}$. From these, the one with the $80 \%$ yield (denoted as BCAR2p in Table 2) is assumed to have a higher volatility and further react with $\mathrm{OH}, \mathrm{O}_{3}$ and $\mathrm{NO}_{3}$ to produce a completely non-volatile second-generation SOA compound (Hoffmann et al., 1997). BCAR2p is the only SOA compound in the presented scheme, for which secondary reactions are allowed. Aerosol yields for isoprene and $\beta$-caryophyllene are provided in Table 2.

\section{Description of simulations}

We performed a reference simulation (S1) with the standard setup for the representation of SOA production from the oxidation of isoprene (described in Sect. 2). This simulation is most compatible with the base simulation of Tsigaridis and Kanakidou (2003), but in addition oxidation chemistry of isoprene is included. The simulated period is 13 months, from June 2002 to June 2003 (coinciding with the period of field observations), with a spin-up time of 5 months. All sensitivity simulations are compared to $\mathrm{S} 1$. To investigate the uncertainties of a number of processes relevant for the formation and removal of SOA from isoprene oxidation over Europe, we carried out a set of additional sensitivity runs for the 3-months summer period June to August 2002 (JJA 2002) with a spin-up time of one month each. We focussed on the summer period since the highest emission of BVOC from the vegetation in Europe occur between June and August (Steinbrecher et al., 2009) and therefore production of SOA precursors from the oxidation of biogenic VOC will be most relevant during that period. We focus on several key-uncertainties in the model representation of SOA formation from isoprene in Europe and analyse and present them in a coherent way. The sensitivity studies were chosen based on the major processes that control the atmospheric fate of SOA: emissions of isoprene, emissions of primary carbonaceous aerosol, dependence of SOA formation on temperature and $\mathrm{NO}_{\mathrm{x}}$ levels, wet removal and the amount and nature of the absorbing aerosol. A lower limit of SOA formation from TM5 was defined with a simulation neglecting the SOA production from isoprene oxidation. The sensitivity runs are summarised in Table 3. 
Table 3. Outline of simulations performed in this work.

\begin{tabular}{ll}
\hline Simulation & Description \\
\hline $\mathrm{S} 1$ & Base simulation (reference): standard setup as described in Sect. 2 (13 months) \\
$\mathrm{S} 1.1 \mathrm{a}$ & Isoprene emissions from global MEGAN inventory \\
$\mathrm{S} 1.1 \mathrm{~b}$ & New European isoprene standard emissions potentials \\
$\mathrm{S} 1.2$ & $\mathrm{NO}_{\mathrm{x}}$ dependence of isoprene SOA yields \\
$\mathrm{S} 1.3 \mathrm{a}$ & Temperature dependence of isoprene SOA, $\Delta H_{\mathrm{vap}}=72.7 \mathrm{~kJ} \mathrm{~mol}^{-1}$ \\
$\mathrm{~S} 1.3 \mathrm{~b}$ & Temperature dependence of isoprene SOA, $\Delta H_{\mathrm{vap}}=11 \mathrm{~kJ} \mathrm{~mol}^{-1}$ \\
$\mathrm{~S} 1.4 \mathrm{a}$ & Wet removal of isoprene oxidation products, $H=10^{5} \mathrm{M} \mathrm{atm}^{-1}$ \\
$\mathrm{~S} 1.4 \mathrm{~b}$ & Wet removal of isoprene oxidation products, $H=10^{6} \mathrm{M} \mathrm{atm}^{-1}$ \\
$\mathrm{~S} 1.5$ & New European BC/POC emission inventory \\
$\mathrm{S} 1.6$ & Irreversible sticking \\
$\mathrm{S} 2$ & Best guess (13 months; see Sect. 3.6) \\
$\mathrm{S} 2.1$ & S2, without condensation on ammonium and sulphate aerosols \\
$\mathrm{S} 3$ & No isoprene-SOA formation(13 months); otherwise as S1 \\
\hline
\end{tabular}

In addition to the reference simulation $\mathrm{S} 1, \mathrm{~S} 2$ includes a number of recent insights in SOA formation from isoprene oxidation, and was run for 13-months. S2 is intended to represent our best guess on SOA formation from isoprene with the presented two-product model approximation, but has certainly a degree of subjectivity as to the exact choice of parameterisations and parameters. The choices for the updated simulation S2 are summarised and justified in Sect. 3.6.

Thus, $\mathrm{S} 1$ allows to understand our model results in the context of previous studies, whereas S2 evaluates the combined impact of recent insights on SOA formation in general, and from isoprene in particular. A number of dedicated sensitivity studies help with understanding which processes contribute to changed results.

\subsection{Isoprene emissions: sensitivity studies S1.1a and S1.1b}

An extensive overview of uncertainties in global isoprene emissions is given by Wiedinmyer et al. (2004). Global isoprene emission estimates have an overall uncertainty factor of 3 (250-750 $\mathrm{TgC}^{-1}$ ) and European isoprene emission estimates vary between 3 and $9 \mathrm{Tg} \mathrm{Cyr}^{-1}$ (Simpson et al., 1999; Steinbrecher et al., 2009). Since we cannot evaluate all individual uncertainties (e.g. emission factors, foliar biomass densities, tree phenology) related to isoprene emissions, we use the more recent inventories by Guenther et al. (2006) and Karl et al. (2009) to evaluate their overall impact.

In case $\mathrm{S} 1.1 \mathrm{a}$ isoprene emissions are simulated using the recent global MEGAN inventory (Guenther et al., 2006) instead of the global GEIA inventory (Guenther et al., 1995). This case involves a change of the isoprene emission inventory and temporal emission characteristics, since the MEGAN algorithm for temperature and light dependence of isoprene emissions is applied instead of the Guenther (1997) parameterisation in simulation S1.
The new European BVOC emission inventory of Karl et al. (2009) uses detailed land use information and updated plantspecific standard emission factors for isoprene and other BVOC. In case S1.1b, isoprene standard emission factors for Europe used in the reference simulation (described in Sect. 2.3) are replaced by emission factors from the new BVOC inventory by Karl et al. (2009), while for the rest of the globe the original emission factors were kept. Thus except for Europe, isoprene emissions in this case correspond to the emissions from the GEIA inventory. The dependence on temperature and light according to Guenther (1997) is applied, as in the reference simulation.

\subsection{Parameterisation of isoprene SOA formation: case $\mathrm{S1.2}$ and $\mathrm{S1.3}$}

Two determining factors controlling SOA formation from isoprene in the gas-particle partitioning model have been selected for further sensitivity analyses: the $\mathrm{NO}_{\mathrm{x}}$ dependence of yields and the temperature dependence of partitioning coefficients.

As proposed by Presto et al. (2005b) for $\alpha$-pinene and Song et al. (2005) for xylene, SOA formation yields and products depend on the $\mathrm{VOC} / \mathrm{NO}_{\mathrm{x}}$ ratio (ppbvC/ppbv). The inclusion of $\mathrm{VOC} / \mathrm{NO}_{\mathrm{x}}$ ratio dependent SOA formation reduced the production of biogenic SOA by about $20 \%$ and increased anthropogenic SOA by $20 \%$ in their global simulations. SOA formation from isoprene has been found to be different at low and high $\mathrm{VOC} / \mathrm{NO}_{\mathrm{x}}$ ratios (Kroll et al., 2006).

The observed dependence of the SOA yield on the $\mathrm{NO}_{\mathrm{x}}$ levels is a consequence of the competing organic peroxy $\left(\mathrm{RO}_{2}\right)$ radical reaction pathways in the oxidation of the parent VOC. At high $\mathrm{NO}_{\mathrm{x}}, \mathrm{RO}_{2}$ is efficiently converted into the alkoxy radical (RO) via reaction with NO. The further fate of the RO radical depends on the structure of the parent VOC, leading mainly to aldehydes, ketones, hydroxycarbonyls, and 
different PAN-like compounds that all have high volatility. An alternative terminating channel of the reaction of $\mathrm{RO}_{2}$ with $\mathrm{NO}$ is the production of organic nitrates, which may be relatively volatile (Presto et al., 2005b). At low $\mathrm{NO}_{\mathrm{x}}$ levels, reactions of $\mathrm{RO}_{2}$ with $\mathrm{HO}_{2}$ and the self- and cross-reactions of $\mathrm{RO}_{2}$ become competitive and are the dominant reactions for $\mathrm{NO}_{\mathrm{x}}$-free conditions. The $\mathrm{RO}_{2}$ reaction with $\mathrm{HO}_{2}$ in general leads to the formation of low-volatile hydroperoxides. In the photo-oxidation of isoprene under low $\mathrm{NO}_{\mathrm{x}}$ conditions, major SOA products are 2-methyltetrols, C5-alkene triols and organic peroxide oligomers (Böge et al., 2006; Surratt et al., 2006). For high $\mathrm{NO}_{\mathrm{x}}$, major SOA products are acidic oligoesters with 2-methylglyceric acid as key monomer (Surratt et al., 2006).

In the work of Henze and Seinfeld (2006), the two-product approach for isoprene was based on low- $\mathrm{NO}_{\mathrm{x}}$ chamber experiments performed by Kroll et al. (2006). The ratio of $\mathrm{VOC} / \mathrm{NO}_{\mathrm{x}}$ is used in the current implementation to study the sensitivity of isoprene derived SOA towards different $\mathrm{NO}_{\mathrm{x}}$ regimes (case S1.2). A fixed $\mathrm{VOC} / \mathrm{NO}_{\mathrm{x}}$ ratio of 8 is used as a threshold to divide between high and low $\mathrm{NO}_{\mathrm{x}}$ regimes, as proposed by Presto et al. (2005b) for $\alpha$-pinene. The linear combination of the virtual SOA compounds produced from the two product model represents the sum of the above stated photo-oxidation products. At high $\mathrm{NO}_{\mathrm{x}}$ conditions (i.e. low VOC/NO $\mathrm{NO}_{\mathrm{x}}$ ) the production of the more volatile product is favoured; while at low $\mathrm{NO}_{\mathrm{x}}$ conditions the production of the less volatile product increases. In the two-product approach for isoprene, the yields from Henze and Seinfeld (2006) apply for high $\mathrm{VOC} / \mathrm{NO}_{\mathrm{x}}$ (i.e. low $\mathrm{NO}_{\mathrm{x}}$ levels). These yields were scaled with the $\mathrm{NO}_{\mathrm{x}}$-dependence of $\alpha$-pinene, as described by Tsigaridis and Kanakidou (2007), to obtain the yields for low $\mathrm{VOC} / \mathrm{NO}_{\mathrm{x}}$.

As we focus on the uncertainties of isoprene SOA production, the $\mathrm{NO}_{\mathrm{x}}$-dependence for compounds other than isoprene is not considered in our simulations, but they are expected to be of importance as well (Tsigaridis et al., 2006).

The partitioning between gas and aerosol phases is calculated with the assumption of equilibrium using gas-particle partitioning coefficients $K_{p, i, j}$ for the product $j$ from the oxidation of hydrocarbon $i$. The influence of temperature on the partitioning coefficient of semi-volatile organics is given by:

$K_{p, i, j}(T)=K_{p, i, j}\left(T_{r}\right) \frac{T}{T_{r}} \exp \left[\frac{\Delta H_{\mathrm{vap}, i, j}}{R}\left(\frac{1}{T}-\frac{1}{T_{r}}\right)\right]$

here, $K_{p, i, j}\left(T_{r}\right)$ is the partitioning coefficient determined in smog chamber experiments at a reference temperature $T_{r}$, and $T$ is the temperature of interest. The enthalpy of vaporisation, $\Delta H_{\mathrm{vap}, i, j}$, has been found to be a key parameter for the correct prediction of SOA concentrations, especially in the upper troposphere where temperatures are low (Pun et al., 2003; Tsigaridis and Kanakidou, 2003). In the reference simulation S1 a value of $42 \mathrm{~kJ} \mathrm{~mol}^{-1}$ is used for isoprene SOA formation, based on the work of Henze and Seinfeld (2006) and previous model studies (e.g. Chung and Seinfeld,
2002). To test the uncertainty of the enthalpy of vaporisation, a high value of $72.7 \mathrm{~kJ} \mathrm{~mol}^{-1}$ adopted from Pun et al. (2002) is used in case S1.3a. Recent laboratory measurements have reported values of $11-44 \mathrm{~kJ} \mathrm{~mol}^{-1}$ at $298-573 \mathrm{~K}$ for the enthalpy of vaporisation (Offenberg et al., 2006), therefore we use a low value of $11 \mathrm{~kJ} \mathrm{~mol}^{-1}$ in case $\mathrm{S} 1.3 \mathrm{~b}$. The enthalpies of vaporisation for all other SOA compounds remain unchanged in the sensitivity tests.

\subsection{Wet removal of isoprene gas phase products: case $\mathrm{S1.4}$}

Wet scavenging is the most efficient process to remove organic aerosols from the atmosphere (Kanakidou et al., 2005). Here we want to study how wet scavenging of semi-volatile organic vapours from isoprene oxidation affects SOA burden over Europe, as it has been relatively poorly explored in previous studies. The wet deposition of gas phase species depends on their solubility in cloud droplets according to their Henry law constants. The parent hydrocarbons are only poorly soluble and therefore no wet deposition is assumed for these compounds. The semi-volatile oxidation products are known to be more soluble than the parent hydrocarbons, but the exact physico-chemical characteristics are important. From the compilation of the Henry's law coefficients by Sander (1999), an average value of $10^{3}-10^{4} \mathrm{M} \mathrm{atm}^{-1}$ is given for monocarboxylic acids and $10^{6}-10^{8} \mathrm{M} \mathrm{atm}^{-1}$ for dicarboxylic acids. In the standard SOA parameterisation of the reference simulation $\mathrm{S} 1$ for all gas phase oxidation products of SOA precursors a Henry coefficient of $10^{3} \mathrm{M} \mathrm{atm}^{-1}$ was used, assuming that the semi-volatile organic gases from the oxidation of parent hydrocarbons (primary oxidation products) are mainly monocarboxylic acids. We note that precipitation scavenging of gases with a Henry's law coefficient $(H)$ equal or below to $10^{3} \mathrm{M} \mathrm{atm}^{-1}$ is small or negligible, unless they dissociate in solution (Crutzen and Lawrence, 2000).

In case S1.4a, the Henry's law coefficient $H=10^{5} \mathrm{Matm}^{-1}$ is used for the wet removal of semivolatile organic gas-phase products from isoprene oxidation. This value has been applied by Henze and Seinfeld (2006) as an average value for SOA compounds. In a further test, $\mathrm{S} 1.4 \mathrm{~b}$, the Henry coefficient for gaseous products from isoprene oxidation was increased to $10^{6} \mathrm{M} \mathrm{atm}^{-1}$. For these test cases the temperature dependence of the Henry coefficient was considered, which can be described by:

$\frac{d \ln H}{d T}=\frac{\Delta H_{A}}{R T^{2}}$

In this equation, $\Delta H_{A}$ is the heat of dissolution and equals to $-12 \mathrm{~K}$ for the semi-volatile gases (Chung and Seinfeld, 2002).

\subsection{Emissions of POC and BC: case S1.5}

There are still tremendous uncertainties associated with the emissions of POC and BC. We explore the impact of these 
uncertainties by utilizing two markedly different inventories. In our reference simulation S1 we use the Bond et al. (2004) with global annual fossil fuel and biofuel combustion emissions of $4.7 \mathrm{Tg} \mathrm{C} \mathrm{BC}$ and $8.8 \mathrm{Tg} \mathrm{C}$ POC. European emissions are $0.51 \mathrm{Tg} \mathrm{C} \mathrm{BC}$ and $1.59 \mathrm{Tg} \mathrm{C} \mathrm{POC} \mathrm{yr}^{-1}$. A detailed European inventory for anthropogenic emitted POC/BC particles, including emissions from fossil fuel and biofuel usage, has been compiled by Guillaume and Liousse (2004). The European dataset is provided with a resolution of $25 \mathrm{~km} \times 25 \mathrm{~km}$ for the year 2000 and makes use of the consumption data from the IIASA database which considers fuel technology details. The inventory for Europe was regridded on $1 \times 1$ degrees horizontal resolution and merged with the global inventory from Junker and Liousse (2008) for the years 2002 and 2003 , which is provided with $1 \times 1$ degrees horizontal resolution. In this inventory, emissions for the world are 5.8 Tg C BC and 9.6 Tg C POC and European emissions are $0.32 \mathrm{Tg} \mathrm{C} \mathrm{BC}$ and $1.24 \mathrm{Tg}$ C POC, respectively. For Europe, $\mathrm{BC}$ and $\mathrm{POC}$ emissions from fossil fuel and biofuel combustion are thus 26\% lower than in the Bond et al. (2004) inventory. Case S1.5 is intended to demonstrate the uncertainty of SOA related to the application of different primary BC/POC emission inventories for Europe due to changes of the magnitude and the distribution of available primary carbonaceous aerosol for the condensation of SOA.

\subsection{Impact of irreversible sticking: case S1.6}

In case S1.6 the possibility of irreversible (physical and/or chemical) transformation of condensed vapours on particles to increase SOA production is explored. Acid-catalysed heterogeneous reactions, e.g. aldol condensation, polymerization, hemiacetal and acetal formation, on particles were suggested to be involved in the formation of low-volatile organic products from aldehydes (Jang and Kamens, 2001; Jang et al., 2002, 2003). Iinuma et al. (2004) found that acid catalysis increased the yield of particle phase organics by $40 \%$ during ozonolysis experiments with ammonium sulphate seed particles. Recent smog chamber experiments of Kroll et al. (2007) found that yields of SOA from the photo-oxidation of aromatic hydrocarbons are enhanced when ammonium sulphate is present compared to non-seeded experiments. They suggest that irreversible processes as heterogeneous reactions or loss on the aerosol surface are involved in SOA formation. Irreversible sticking of SOA implies that once semi volatile organic gases condense, SOA is formed and the organics remain in the particulate phase, and are not allowed to evaporate from the particle. In this sensitivity case, we assume that a process of physical trapping and/or chemical transformation (ageing reaction) is involved, which leads to the irreversible conversion of particle-phase SOA to a nonvolatile compound. The exact nature of the physical trapping or aging reaction remains unknown. At every time step, equilibrium partitioning following Eq. (1) is established between the gas-phase and particle-phase SOA compound. Between the current and the next model time step this physical and/or chemical trapping occurs, transforming all SOA present in the aerosol phase into a non-volatile compound. Thus SOA in the aerosol phase becomes part of the non-volatile OA, similarly to the primary carbonaceous aerosol in the model. At the next model time step, the cycle closes with a new equilibrium between gas-phase and the newly absorbed aerosol phase SOA. Thus the time span between the time steps defines the time scale on which the trapping/conversion processes occur. In terms of a vapour loss process this means that we assign an absolute lifetime (not an e-folding lifetime) to the semi-volatile vapour towards trapping/conversion processes on the aerosol which equals the model's time step of $11 \mathrm{~min}$ (in the $1^{\circ} \times 1^{\circ}$ zoom region) to $45 \mathrm{~min}$ (on the global $6^{\circ} \times 4^{\circ}$ scale).

Partitioning models that take acid-catalyzed reactions and/or oligomerisation reactions into account are under development (Jang et al., 2006; Pun and Seigneur, 2007) but currently not feasible for implementation in a global chemistry transport model (CTM). As more data becomes available from chamber experiments on the different chemical and physical transformations of SOA in the particle phase, more suitable parameterizations for use in CTMs may be derived in the future. Condensation of organics on ammonium and sulphate aerosol is allowed in case S1.6. Test case S1.6 can be seen as the case with maximum possible SOA production from the current approach with the standard partitioning parameters and corresponds to scenario S4 in the work of Tsigaridis and Kanakidou (2003) in which a total annual production rate of about $48 \mathrm{Tg}$ SOA was obtained.

\subsection{The combined impact of the updated parameterisa- tion, $\mathrm{S} 2$ and $\mathrm{S3}$}

A combination of parameters representing our best guess of SOA formation from the oxidation of isoprene is assembled for case S2. For the updated simulation (S2) we use the MEGAN inventory of isoprene emissions, which is increasingly used in global atmospheric models (e.g. Müller et al., 2008) and is currently extended to other BVOC than isoprene (Sakulyanontvittaya et al., 2008). The dependence of isoprene SOA on the VOC/NO ${ }_{x}$ ratio (Kroll et al., 2006) is taken into account in S2. We chose the value $\Delta H_{\mathrm{vap}}=42 \mathrm{~kJ} \mathrm{~mol}^{-1}$ for the temperature dependence of the partitioning, since it is in exact agreement with the recent experimentally derived effective enthalpy of vaporization of SOA from isoprene oxidation (Kleindienst et al., 2007a). Semi-volatile products identified in the oxidation of isoprene, in particular tetrols (Claeys et al., 2004b; Edney et al., 2005), are much more soluble than monocarboxylic acids. We assume that $H=10^{5} \mathrm{M} \mathrm{atm}^{-1}$ is currently the best guess of the Henry coefficient for isoprene oxidation products. The Bond et al. (2004) inventory of primary carbonaceous emissions was selected, since calculated spatial distributions of European BC concentrations are in good agreement with station observations in Europe 
(E. Vignati, unpublished data, 2008). Further, we decided to allow for condensation of SOA on ammonium and sulphate aerosol in addition to condensation on particulate organic matter. The relevance of irreversible sticking to particles has not been quantified on atmospheric scales. We therefore allow for the evaporation of previously condensed vapours from particles. In summary our best guess parameterisation for the processes related to SOA formation from isoprene oxidation in $\mathrm{S} 2$ is:

1. MEGAN isoprene emission inventory and emission algorithm;

2. $\mathrm{NO}_{\mathrm{x}}$-dependence of semi-volatile oxidation products from isoprene oxidation;

3. Enthalpy of vaporisation $\Delta H_{\mathrm{vap}}=42 \mathrm{~kJ} \mathrm{~mol}^{-1}$;

4. Wet scavenging of gaseous isoprene oxidation products with $H=10^{5} \mathrm{M} \mathrm{atm}^{-1}$;

5. Bond et al. (2004) inventory of primary carbonaceous emissions;

6. Additional condensation on ammonium and sulphate;

7. With evaporation.

In a further three month summer period June to August 2002, $\mathrm{S} 2.1$, the effect of the additional condensation on ammonium and sulphate aerosols was tested for the SOA parameterisation of S2. In this simulation the same parameterisation as in $\mathrm{S} 2$ is used but without condensation of semi volatile gases on ammonium and sulphate aerosols. We included this process sensitivity to obtain a lower limit estimate for the updated model parameterisation.

In a final case simulation, S3, the effect of omitting SOA formation from isoprene is investigated. This simulation is done to provide the lower-limit estimate of SOA over Europe and to demonstrate the potential importance of isoprene SOA. All other parameters in S3 were identical to S1. The cases S1, S2, and S3 were run for 13-months June 2002 to June 2003.

\section{Results and discussion}

In Sect. 4.1 we start with presenting sensitivity results. Changes in the European SOA surface concentrations distribution compared to the reference simulation results are described. From the investigated cases, three scenarios have been selected for a more detailed analysis of the SOA budget (production rates, burden, boundary layer budget, export) together with a comprehensive comparison of particulate organic matter concentrations with surface station observations (Sect. 4.2). The three scenarios are the reference simulation $\mathrm{S} 1$, the updated simulation $\mathrm{S} 2$ (most recent insights included) and S3 (no formation of isoprene SOA), each covering a simulation period of 13 months. The relevance of SOA from the oxidation of isoprene in S1 and S2 becomes evident by comparison of these scenarios to S3. In Sect. 4.3 we compare our SOA budget results on the global scale to previous global SOA model studies. This is followed by a comparison with a recent regional model study on carbonaceous aerosol over Europe (Sect. 4.4).

\subsection{Uncertainties on European SOA}

\subsubsection{Sensitivity of summertime SOA surface concentration distributions}

Distributions of the differences with S1 of European SOA (from isoprene as well as terpenes) surface concentrations in JJA (June to August) 2002 are shown in Fig. 1 for selected sensitivity studies. Using the MEGAN isoprene emission inventory and emission parameterisation (S1.1a) SOA decreases by on average $20 \%$ in Europe (Fig. 1a). MEGAN isoprene emissions are lower by a factor of two compared to the GEIA emissions in $\mathrm{S} 1$. This leads to a reduction of the SOA production and burden over Europe of about $20 \%$ and $30 \%$. The reductions are largest over Spain, where SOA concentrations decrease by up to $40 \%$, while SOA concentrations remain almost unchanged over Croatia and parts of Scandinavia.

Using European isoprene standard emission factors from Karl et al. (2009) (S1.1b) decreases SOA in all parts of Europe compared to the GEIA inventory based estimate (Fig. 1b). Similar to case S1.1a, reductions are highest over Spain, where SOA concentrations decrease by up to $50 \%$.

Applying the $\mathrm{NO}_{\mathrm{x}}$ dependence of isoprene SOA yields (S1.2) leads to a decrease of SOA by $10-30 \%$ over most rural regions of Europe, while SOA concentrations increase by $10-20 \%$ over urban regions (Fig. 1c). In Europe, low $\mathrm{VOC} / \mathrm{NO}_{\mathrm{x}}$ (high $\mathrm{NO}_{\mathrm{x}}$ ) conditions prevail, with VOC/NO $\mathrm{N}_{\mathrm{x}}<8$, which cause a reduction of SOA surface concentrations. The yield of the more volatile products from isoprene oxidation is roughly doubled under low $\mathrm{VOC} / \mathrm{NO}_{\mathrm{x}}$ compared to high $\mathrm{VOC} / \mathrm{NO}_{\mathrm{x}}$. The surface concentration of semi-volatile gaseous oxidation products over Europe increases on average by $30 \%$ compared to $\mathrm{S} 1$. The rather long lifetime of semi-volatile gaseous compounds $(\approx 3 \mathrm{~d})$ facilitates the transport of these compounds into areas where they condense on pre-existing aerosols. The increased concentration of gas phase products may lead to an increase of the SOA concentration, if sufficient primary carbonaceous particles are available for condensation. This is the case over urban and industrialised regions, in particular if these are downwind of forested areas.

We note that in chamber studies, which are often carried out with elevated concentrations of the parent VOC, the importance of $\mathrm{RO}_{2}$ self- and cross-reactions tends to be more important than they are in the real atmosphere. Under 

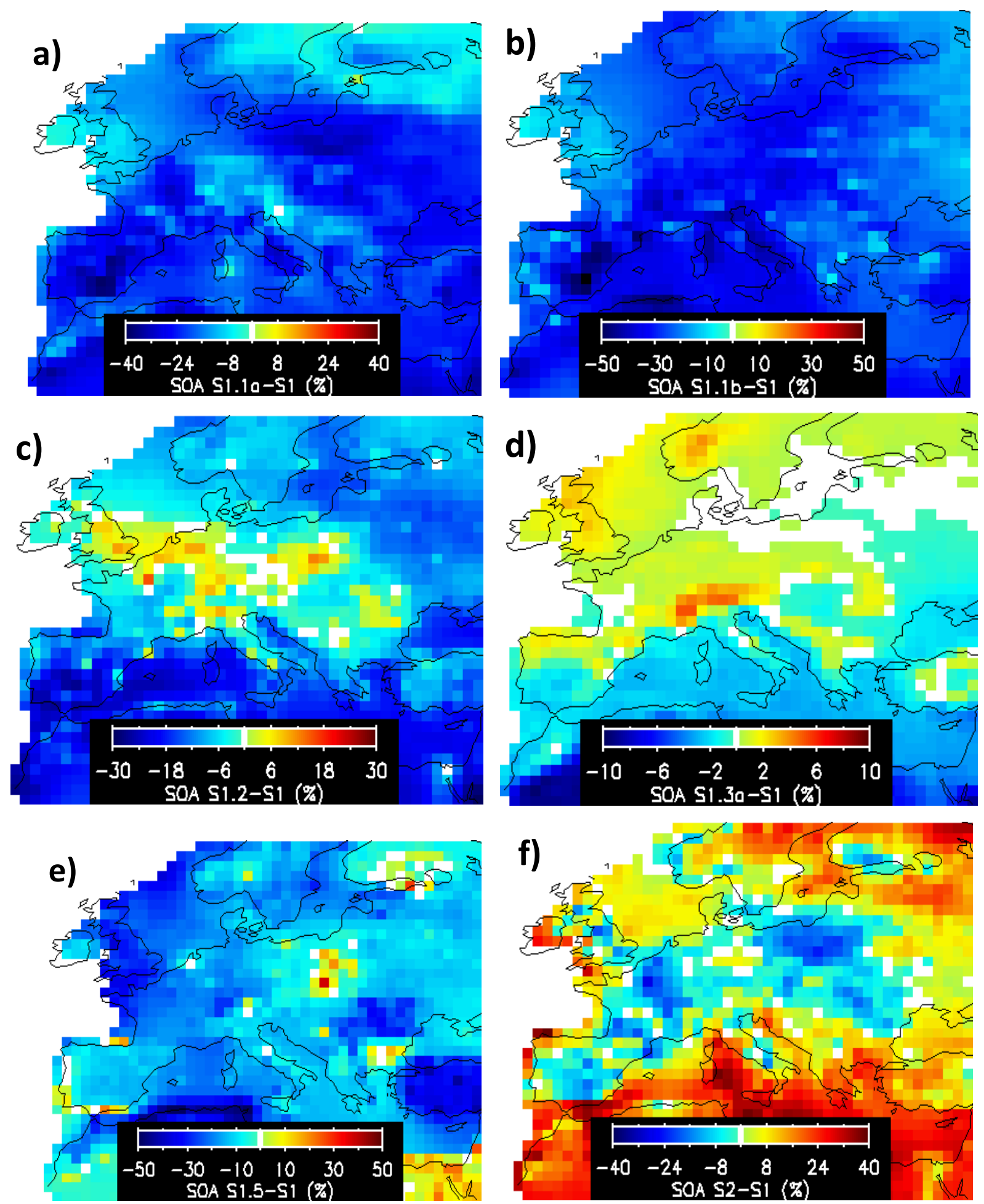

Fig. 1. Relative differences of surface SOA between sensitivity cases and the reference simulation S1 over Europe for JJA 2002: (a) S1.1a, using MEGAN isoprene emissions; (b) S1.1b, using European isoprene standard emission factors from Karl et al. (2009); (c) S1.2, applying the $\mathrm{NO}_{\mathrm{x}}$ dependence of isoprene SOA; (d) $\mathrm{S} 1.3 \mathrm{a}$, applying $\Delta H_{\mathrm{vap}}=72.7 \mathrm{~kJ} \mathrm{~mol}^{-1}$ for the temperature dependence of $K_{\mathrm{p}}$ for isoprene oxidation products; (e) S1.5, replacing the BC/POC fossil fuel/biofuel emission inventory with a detailed technology based European inventory; (f) S2, using the combination of parameters according to current state of knowledge. Changes are only plotted for areas where SOA surface concentrations are above $0.25 \mathrm{\mu g} \mathrm{m}^{-3}$. Thus white colors either indicate low concentrations or small changes. 
atmospheric conditions, $\mathrm{HO}_{2}$ is often the major or even the only reaction partner of the organic peroxy radicals under low- $\mathrm{NO}_{\mathrm{x}}$ conditions. Thus the use of the $\mathrm{NO} / \mathrm{HO}_{2}$ ratio seems more appropriate for extrapolating results from environmental chamber conditions to atmospheric conditions (e.g. Henze et al., 2008), and should replace the $\mathrm{VOC} / \mathrm{NO}_{\mathrm{x}}$ in future model studies.

Changing the enthalpy of vaporisation changes the temperature dependence of the isoprene SOA partitioning coefficient ( $\mathrm{S} 1.3 \mathrm{a}$ and b). Using $\Delta H_{\mathrm{vap}}=72.7 \mathrm{~kJ} \mathrm{~mol}^{-1}$ for isoprene oxidation products leads to an increase of SOA over cold regions (Alps, UK, Norway) by up to $8 \%$, while it decreases over hot regions (Sahara desert) by up to $10 \%$ (Fig. 1d). The temperature threshold that turns the SOA behaviour from increase to decrease when the enthalpy of vaporisation changes is the temperature where the chamber experiments were performed $(295 \mathrm{~K}$ in the case of isoprene), as demonstrated by Tsigaridis and Kanakidou (2003). Using $\Delta H_{\text {vap }}$ of $11 \mathrm{~kJ} \mathrm{~mol}^{-1}$ (Fig. S1a in the Electronic Supplement (see http://www.atmos-chem-phys.net/9/ 7003/2009/acp-9-7003-2009-supplement.pdf). has the reversed effect, with decreases of SOA by up to $10 \%$ in the cold regions and increases by up to $20 \%$ over the Sahara desert.

Wet scavenging of isoprene oxidation products (Fig. S1b, Electronic Supplement http://www.atmos-chem-phys.net/9/ 7003/2009/acp-9-7003-2009-supplement.pdf) with a Henry law coefficient $H$ of $10^{5} \mathrm{Matm}^{-1}$ (S1.4a) causes largest reductions of SOA surface concentrations over Great Britain and the Alps, where precipitation is most frequent. A further decrease of $H$ to $10^{6} \mathrm{M} \mathrm{atm}^{-1}$ (S1.4b) has a negligible effect on European SOA (not shown) since the oxidation products from isoprene seem to be effectively soluble beyond $H=10^{5} \mathrm{M} \mathrm{atm}^{-1}$, in agreement with the work of Henze and Seinfeld (2006).

Replacing our standard BC/POC fossil fuel/biofuel emission inventory (Bond et al., 2004) with a detailed technology based European inventory (S1.5) (Junker and Liousse, 2008; Guillaume and Liousse, 2004) changes the distribution of pre-existing carbonaceous aerosols over Europe. It leads to SOA increases of up to $50 \%$ over Poland and Israel but reduces SOA over Great Britain, Northern Africa, Turkey and Romania by $30-50 \%$ (Fig. 1e).

The consideration of irreversible sticking (physical trapping/chemical transformation) of semi-volatile organics (S1.6) on carbonaceous, ammonium and sulphate aerosols increases the European SOA concentrations roughly by a factor of 4 compared to S1 (Fig. S1c, Electronic Supplement http://www.atmos-chem-phys.net/9/7003/2009/ acp-9-7003-2009-supplement.pdf). This is the maximum increase that can be achieved with the current parameterisation, without changing the compound's vapour pressure values.

The results obtained for S2 (best guess parameterisation) are more difficult to interpret, since several parameters relevant to SOA formation from isoprene are changed simultaneously compared to $\mathrm{S} 1$. The chosen parameter combination is based on the current state of knowledge and changes of the SOA production might be due to changed isoprene emissions, wet deposition of oxidation products, and the $\mathrm{NO}_{\mathrm{x}}$ dependence. In S2 the additional inorganic aerosol mass available for condensation partly compensates for the reduction caused by the changes in the isoprene SOA formation. Over Central Europe and Spain the SOA surface concentration changes are moderate with a rather uniform decrease by up to $10 \%$ compared to S1 (Fig. 1f). In parts of the Mediterranean and in Scandinavia the use of MEGAN emissions only slightly reduced SOA concentrations (Fig. 1a). In these regions an increase by 10 to $30 \%$ compared to $\mathrm{S} 1$ is found in S2. In S2.1 the same parameterisation as in S2 was used but without condensation on ammonium and sulphate. As a consequence, European SOA surface concentrations decrease uniformly by 10 to $30 \%$ (Fig. S1d, Electronic Supplement http://www.atmos-chem-phys.net/9/7003/2009/ acp-9-7003-2009-supplement.pdf).

Without SOA formation from isoprene oxidation (S3), surface concentrations are reduced by 30-50\% over Europe (Fig. S1e, Electronic Supplement http://www.atmos-chem-phys.net/9/7003/2009/ acp-9-7003-2009-supplement.pdf).

\subsubsection{Production rates and burden}

In Table 4 the total European and global SOA production rate and burden resulting from simulations S1, S2 and $\mathrm{S} 3$ are summarized. The production in $\mathrm{S} 1$ amounts to $1 \mathrm{Tg} \mathrm{yr}^{-1} \mathrm{SOA}$ resulting from terpenes, isoprene and aromatic hydrocarbons and a mean burden of about $50 \mathrm{Gg}$ SOA (S2: $32 \mathrm{Gg} \mathrm{SOA}$ ) in the atmosphere over Europe (from surface up to $10 \mathrm{hPa}$ ) is computed for the period from July 2002 to June 2003. This is within 20\% (S2: 50\%) of the European SOA burden estimated using simulation results from Tsigaridis et al. (2006). The European SOA burden calculated in S1 for August 2002, $6.4 \mathrm{Gg}(\mathrm{S} 2: 4.4 \mathrm{Gg}$ ), is about 50\% (S2: 30\%) higher than the estimate given by Marmer and Langmann (2007) using a regional model (REMOTE). Apart from the cited numbers, we are not aware of other estimates of the atmospheric SOA production and burden over Europe.

The SOA production over Europe decreases by roughly $30 \%$ in S2 compared to S1. The burden of SOA from isoprene oxidation (SOA-I) over Europe decreases much more strongly, from $23 \mathrm{Gg}$ in $\mathrm{S} 1$ to about $6 \mathrm{Gg}$ in S2, mainly due to the lower isoprene emissions and increased wet deposition of the gas-phase products from isoprene oxidation. In contrast, a slight increase of SOA from oxidation of aromatic hydrocarbons (SOA-A) is found in $\mathrm{S} 2$ (from $2.7 \mathrm{Gg}$ in $\mathrm{S} 1$ to $3.8 \mathrm{Gg}$ in $\mathrm{S} 2$ ), due to the additional condensation of semi volatile oxidation products from aromatic hydrocarbons on ammonium and sulphate aerosols. In S3 (no SOA formation from isoprene oxidation), the European SOA production and burden are only half of the production and burden in the base 
Table 4. Chemical production and burden of total SOA, isoprene derived SOA (SOA-I), SOA from terpenes (SOA-T) and anthropogenic SOA (SOA-A) in the European atmosphere (upper panel) and global atmosphere (lower panel) from surface up to $10 \mathrm{hPa}$ determined from the one-year simulations (July 2002 to June 2003).

\begin{tabular}{lllllllll}
\hline \multirow{2}{*}{ Case } & \multicolumn{3}{c}{ European production $\left(\mathrm{Tg} \mathrm{yr}^{-1}\right)$} & \multicolumn{5}{c}{ European burden $(\mathrm{Gg})$} \\
& SOA Total & SOA-I & SOA-T & SOA-A & SOA Total & SOA-I & SOA-T & SOA-A \\
\hline S1 & 0.98 & 0.40 & 0.51 & 0.07 & 48 & 23 & 22 & 3 \\
S2 & 0.70 & 0.10 & 0.49 & 0.11 & 32 & 6 & 22 & 4 \\
S3 & 0.51 & 0.00 & 0.44 & 0.07 & 24 & 0 & 21 & 3 \\
\hline \multirow{2}{*}{ Case } & \multicolumn{7}{l}{ Global production $\left(\mathrm{Tg} \mathrm{yr}^{-1}\right)$} \\
& SOA Total & SOA-I & SOA-T & SOA-A & SOA Total & SOA-I & SOA-T & SOA-A \\
\hline S1 & 32.9 & 15.2 & 16.9 & 0.8 & 230 & 119 & 106 & 5 \\
S2 & 20.9 & 3.2 & 16.8 & 0.9 & 143 & 30 & 107 & 6 \\
S3 & 16.9 & 0.0 & 16.1 & 0.8 & 114 & 0 & 109 & 5 \\
\hline
\end{tabular}

simulation S1 (Table 4). This change highlights the importance of secondary organic aerosol from isoprene oxidation in the atmosphere over Europe.

The budget results of the sensitivity simulations (described in Sects. 3.1 to 3.6) of isoprene derived SOA production and burden over the summer (JJA 2002) European PBL (up to $850 \mathrm{hPa})$ and free troposphere $(850-1000 \mathrm{hPa})$ are summarized in Table 5. Wet scavenging of isoprene oxidation products with a Henry coefficient $H$ of $10^{5} \mathrm{M} \mathrm{atm}^{-1}$ (S1.4a) decreases the tropospheric SOA burden by $15 \%$. Further increasing $H$ to $10^{6} \mathrm{M} \mathrm{atm}^{-1}$ (S1.4b) has little effect, meaning that the oxidation products are already effectively scavenged at $H=10^{5} \mathrm{M} \mathrm{atm}^{-1}$. A similar decrease of the tropospheric SOA burden (by 9\%) is observed for the new European $\mathrm{BC} / \mathrm{POC}$ emission inventory (S1.5). Introducing the $\mathrm{NO}_{\mathrm{x}}$ dependence for the yields of oxidation products reduces the SOA production rate by $9 \%$ in the PBL and by $7 \%$ in the troposphere.

The largest change is found in simulation S1.6 (irreversible sticking, condensation also on inorganic aerosol); the European SOA production rate in JJA 2002 increases by almost a factor of 4 compared to $\mathrm{S} 1$. We note that the implementation of irreversible sticking in case S1.6 implies that all condensed aerosol-phase SOA is converted to a nonvolatile compound. In reality only a certain fraction of it will be transformed. Thus the case of irreversible sticking should serve as the upper limit of SOA formation, while the (standard) evaporation case represents the lower limit, and the real situation lies between the two. Oligomer formation has been found to take place almost instantaneously (Hoffmann et al., 1998) but also on a longer time scale through accretion reactions (Kalberer et al., 2006). Irreversible sticking applied in S1.6 is a relatively slow process leading to the irreversible transformation of particle-phase SOA into a non-volatile compound within one model time step of 11 to $45 \mathrm{~min}$, depending on the model scale $\left(1^{\circ} \times 1^{\circ}, 3^{\circ} \times 2^{\circ}\right.$, or $\left.6^{\circ} \times 4^{\circ}\right)$

According to the GEIA inventory, $10 \mathrm{Tg}$ of isoprene are emitted in Europe per year. The total amount of isoprene that is oxidised in simulation $\mathrm{S} 1$ is $6.4 \mathrm{Tg} \mathrm{yr}^{-1}$ (the remainder is transported out of the domain) leading to the formation of $0.4 \mathrm{Tg} \mathrm{yr}^{-1}$ SOA-I. This corresponds to an average (mass based) aerosol yield of $6 \%$ from isoprene oxidation, which is twice higher than the yield derived from low- $\mathrm{NO}_{\mathrm{x}}$ smog chamber experiments $(\approx 3 \%)$. In contrast to chamber experiments, isoprene is emitted continuously to the atmosphere leading to increased SOA yields due to the non-linear dependence on the pre-existing aerosol mass. In particular in Southeastern Europe, high emissions of isoprene (from the GEIA inventory) spatially coincide with high emissions of primary carbonaceous aerosol (BC and POC) leading to significantly higher isoprene SOA concentrations in the region. To illustrate this, European surface concentrations of primary carbonaceous aerosol for July 2002 are shown in Fig. S2 (Electronic Supplement http://www.atmos-chem-phys.net/9/ 7003/2009/acp-9-7003-2009-supplement.pdf).

\subsubsection{Boundary layer budget}

In this section we assess the processes that determine the European secondary organic aerosol budget: dry and wet deposition, vertical and horizontal advection, convection and chemical production. Figure 2 shows for all simulations the mean contribution of major processes to total SOA during JJA 2002 in the PBL over Europe. The purpose of presenting the European budget for SOA during summer is to compare the relative contribution of major aerosol fluxes to the concentration of SOA. Within the budget, each scenario represents a different equilibrium state of the gas phase/particle partitioning of SOA. Thus the presented budget contains the additional dimension of different possible equilibrium states.

A considerable spread for the average tropospheric SOA production rate in JJA 2002 is found, ranging from 
Table 5. Changes of chemical production and burden of SOA derived from isoprene oxidation in the planetary boundary layer (up to $850 \mathrm{hPa}$ ) and the free troposphere ( 850 to $100 \mathrm{hPa}$ ) over Europe (JJA 2002) determined in the sensitivity cases using S1 as reference simulation.

\begin{tabular}{|c|c|c|c|c|}
\hline \multirow{2}{*}{$\begin{array}{l}\text { Test } \\
\text { Case }\end{array}$} & \multicolumn{2}{|c|}{ PBL (up to $850 \mathrm{hPa}$ ) } & \multicolumn{2}{|c|}{ Free troposphere $(850$ to $100 \mathrm{hPa})$} \\
\hline & $\begin{array}{l}\text { Production } \\
\text { Change }(\%)\end{array}$ & $\begin{array}{c}\text { Burden } \\
\text { Change }(\%)\end{array}$ & $\begin{array}{l}\text { Production } \\
\text { Change }(\%)\end{array}$ & $\begin{array}{c}\text { Burden } \\
\text { Change (\%) }\end{array}$ \\
\hline S1.1a & -20 & -25 & -20 & -27 \\
\hline $\mathrm{S} 1.1 \mathrm{~b}$ & -28 & -25 & -27 & -24 \\
\hline $\mathrm{S} 1.2$ & -9 & -11 & -6 & -4 \\
\hline $\mathrm{S} 1.3 \mathrm{a}$ & +3 & -1 & +29 & +44 \\
\hline $\mathrm{S} 1.3 \mathrm{~b}$ & -2 & +1 & -12 & -21 \\
\hline $\mathrm{S} 1.4 \mathrm{a}$ & -15 & -12 & -18 & -19 \\
\hline $\mathrm{S} 1.4 \mathrm{~b}$ & -16 & -13 & -19 & -20 \\
\hline S1.5 & -17 & -12 & -12 & -4 \\
\hline S1.6 & +326 & +330 & +268 & +199 \\
\hline S2 & +7 & 0 & +7 & -9 \\
\hline S2.1 & -38 & -42 & -39 & -45 \\
\hline S3 & -41 & -44 & -42 & -44 \\
\hline
\end{tabular}

$1.4 \mathrm{Gg} \mathrm{d}^{-1}$ when excluding SOA formation from isoprene oxidation up to $9.4 \mathrm{Gg} \mathrm{d}^{-1}$, for the case of condensation of SOA on carbonaceous, ammonium and sulphate aerosols and considering irreversible sticking of semi-volatile organic vapours (maximum case, S1.6). Convection, horizontal and vertical advection will transport SOA out of the PBL into the free troposphere and/or outside the European model domain.

Wet scavenging is the most important process to remove SOA from the atmosphere, while dry deposition of SOA is a minor removal pathway. Recently, Hallquist et al. (2009) suggested that dry and wet deposition of organic vapours (including VOC, IVOC, and semi-volatile vapours) could play an important role in the global budget of organic nonmethane carbon, with an estimated flux of $800 \mathrm{Tg} \mathrm{C} \mathrm{yr}^{-1}$. In terms of "traditional" SOA, dry deposition of semi-volatile vapours is expected to be a minor removal pathway for the total SOA. In our calculations the contribution of dry deposition of semi-volatile vapours to the removal of SOA is less than $15 \%$.

\subsubsection{Aerosol export}

In Fig. 2 we show that in the various scenarios between 7 and $60 \%$ of the SOA formed in the European PBL during summer is exported out of Europe, with $35 \%$ for $\mathrm{S} 1$. This corresponds to an export of $0.21 \mathrm{Tg} \mathrm{yr}^{-1} \mathrm{SOA}$ out the European domain by advection or - to a lesser extent - by transport into higher regions of the atmosphere. Most exported SOA is advected from Europe to Asia. For comparison, Europe exports about $0.23 \mathrm{Tg} \mathrm{yr}^{-1} \mathrm{BC}$ and $0.53 \mathrm{Tg} \mathrm{yr}^{-1}$ POC (PHOENICS Synthesis and Integration Report, 2005; Kanakidou et al., 2005), with the majority of these aerosols being of anthropogenic origin. Thus the amount of SOA exported out of Europe is comparable to that of Black Carbon.

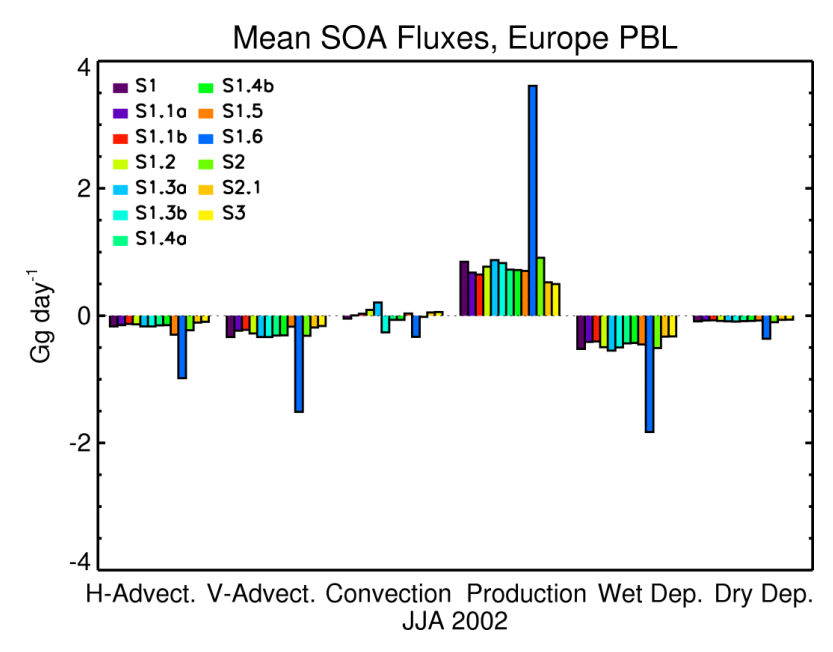

Fig. 2. Sensitivity of SOA processes in the PBL over Europe towards changes of emissions, formation routes, wet removal and nature and amount of absorbing matter. Processes are represented as SOA fluxes (in $\mathrm{Gg} \mathrm{day}^{-1}$ ) from surface up to $850 \mathrm{hPa}$ taken from the 3-monthly average JJA 2002 of the simulations S1 to S1.6, S2, S2.1 and S3. Processes are: horizontal and vertical advection, convection, chemical production, wet and dry deposition.

Over Europe convection is a minor process for transporting SOA out of the PBL to higher altitudes (Fig. 2). Interestingly, the vertical transport of SOA particles to higher altitudes (between 100 and $10 \mathrm{hPa}$ ) is only $14 \%$ of the amount that is directly produced in the atmosphere at high altitudes, indicating the importance of SOA condensation of high volatility products at low temperatures, as was suggested earlier by Tsigaridis et al. (2006). This implies that large amounts of gaseous semi-volatile oxidation products 

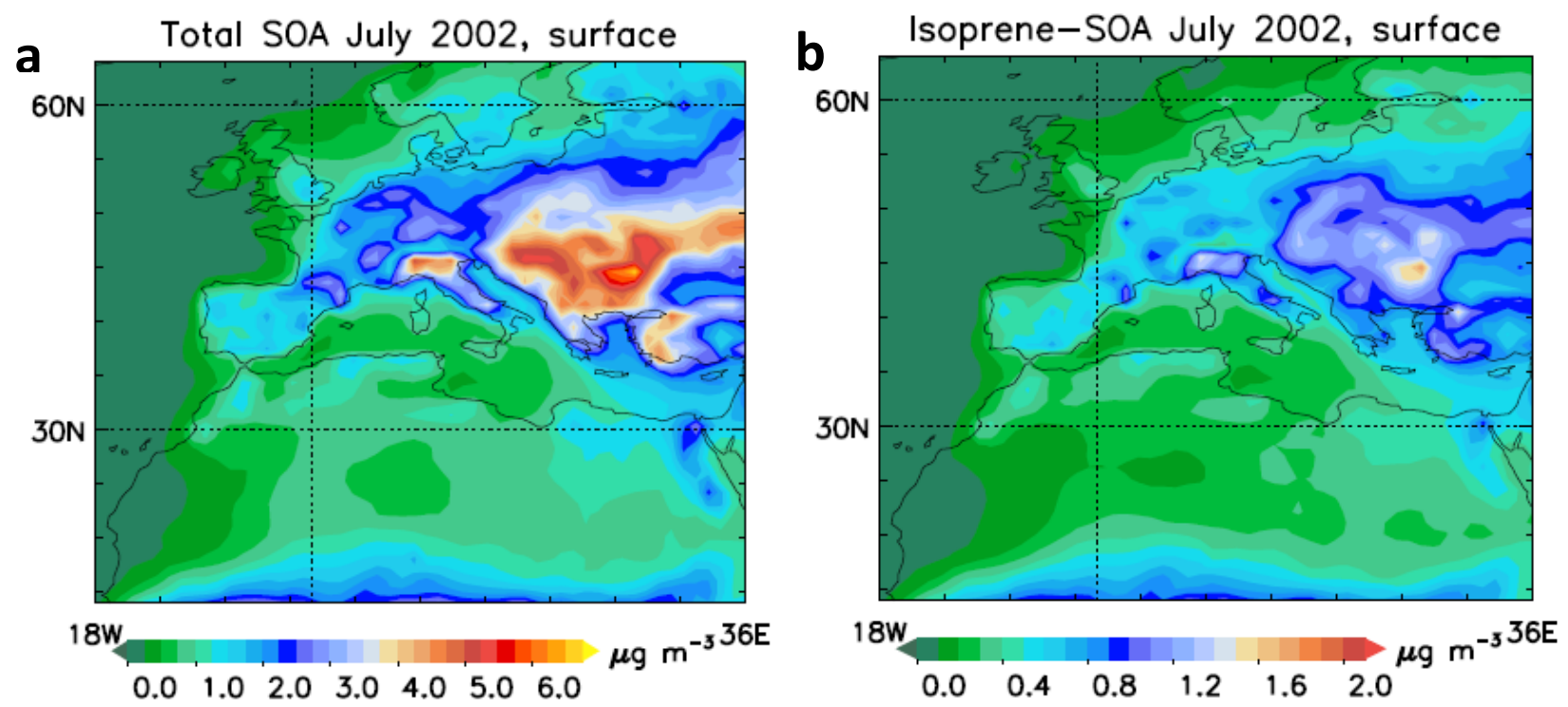

Fig. 3. European distributions of surface concentration of (a) total SOA, and (b) SOA from isoprene oxidation; for the reference simulation S1, July 2002.

are convected. In $\mathrm{S} 1,0.5 \mathrm{Tg} \mathrm{yr}^{-1}$ gaseous semi-volatile compounds are convected to altitudes between 100 and $10 \mathrm{hPa}$.

\subsection{Comparison with ground based observations}

\subsubsection{Surface concentrations of isoprene-derived SOA}

In July 2002, highest SOA surface concentrations of up to $6.8 \mu \mathrm{g} \mathrm{m}^{-3}$ are calculated for South Eastern Europe and Northern Italy for the reference simulation S1 (Fig. 3a). As we will see later, the concentrations calculated in other sensitivity studies are rather similar. The maximum concentration of SOA-I, about $1.8 \mu \mathrm{g} \mathrm{m}^{-3}$, can be found over Southeastern Europe (Fig. 3b). In southern Finland, monthly mean modelled SOA-I concentrations in July 2002 lie between 0.2 and $0.3 \mu \mathrm{g} \mathrm{m}^{-3}$. Unfortunately, there are scarce possibilities to compare these calculations with measurements. Measurements of isoprene oxidation products in a boreal forest at Hyytiälä in southern Finland were a factor of 4 lower, with the lumped sum of SOA from isoprene being only $0.05 \mu \mathrm{g} \mathrm{m}^{-3}$ during summer 2004 (Kourtchev et al., 2005). This corresponded to only $0.8 \%$ of the carbon in Organic Carbon from PM1 aerosol samples. In Hungary, S1 predicts SOA-I concentrations of about $1 \mu \mathrm{g} \mathrm{m}^{-3}$ and higher in July 2002. Much lower concentrations of isoprene oxidation products $\left(0.05 \mu \mathrm{g} \mathrm{m}^{-3}\right)$ have been measured in aerosol samples at K-puzsta, Hungary during summer 2002 (Ion et al., 2005).

One may conclude from this comparison with the few available isoprene SOA measurements in Europe, that SOA-I is over predicted by the parameterisation in S1. However, the measurements considered only a limited amount of oxida- tion products, whereas modelled SOA-I may contain products from the isoprene oxidation that were not measured during these field campaigns. This conclusion is supported by Ion et al. (2005) who state that identified isoprene oxidation products (2-methylglyceric acid and various tetrols) should rather be viewed as marker compounds for isoprene photo-oxidation products and not as total SOA-I. They suggest a large contribution of isoprene oxidation products to the humic-like substances found in the finer aerosol fraction during summer. In south-eastern U.S. ambient SOA-I concentrations, based on measured marker compounds and laboratory-derived SOA mass fractions, were between 0.3 and $2.1 \mu \mathrm{g} \mathrm{m}^{-3}$ during summer 2003 (Kleindienst et al., 2007b). In this region we compute SOA-I concentrations of $0.8-1.2 \mu \mathrm{g} \mathrm{m}^{-3}$ (June-August average), although we must mention that the model was run there at low $6^{\circ} \times 4^{\circ}$ resolution. The good agreement underlines the important role of SOA-I in regions with high isoprene emissions from vegetation.

\subsubsection{EMEP campaign organic carbon observations during 2002-2003}

Model results from S1, S2, and S3 are compared with observations from 13 locations of the EMEP OC/EC measurement campaign 2002/2003 (Fig. 4). During this campaign, daily samples of EC, OC, and TC were analysed along with inorganic aerosol components (Yttri et al., 2007). Measured OC concentrations were converted to organic matter mass (which is output from our model) using the station specific $\mathrm{OM} / \mathrm{OC}$ ratios ranging from 1.4 to 1.8 , provided by Yttri et al. (2007). Highest OC concentrations were reported for 
Central and Southern Europe. Measured annual average OC concentrations were three times higher for the sites in continental Europe compared to sites in Scandinavia and at the British Isles. The highest annual mean concentration (about $13 \mu \mathrm{g} \mathrm{OM} \mathrm{m}^{-3}$ ) was observed at the rural background site Ispra (IT04) in Italy. In addition, model results from the S1 simulation were compared to monthly averaged OC measurements from Finokalia $\left[35^{\circ} 20^{\prime} \mathrm{N}, 25^{\circ} 40^{\prime} \mathrm{E}\right]$. OC in the $\mathrm{PM}_{1.3}$ aerosol fraction has been measured at Finokalia over a period of two years from July 2004 to July 2006 (Koulouri et al., 2008). A OM/OC ratio of 1.8 was used to convert this data to OM mass.

The predicted spatial distribution of OM is consistent with observations over Europe. Figure 4 shows a good spatial correlation $\left(r^{2}=0.66-0.70\right)$ for all three major simulations S1S3 of the yearly averaged OM concentrations for the period of July 2002 to June 2003. However, all simulations underestimate the annual observations by a factor of two to three. The discrepancy cannot be attributed to a possible poor representation of EMEP sites by our model, as the majority is characterised as rural (only two sites being urban background stations). TM5 generally performs well in predicting surface concentrations of the inorganic aerosol, e.g. sulphate, nitrate, and ammonium, over Europe (De Meij et al., 2006). However, depending on which emission inventory is used, differences in the spatial distribution are calculated. Observed surface concentrations of sulphate are matched well when using both the EMEP and the AEROCOM emission inventory; ammonium and nitrate surface concentrations are in better agreement when applying the EMEP emission inventory (De Meij et al., 2006).

To get a better insight into the reasons of discrepancy, we compare in Fig. 5 modelled monthly averaged OM (separated in SOA and POA) for the 3 simulations at five stations representative for Central, Northern and Southern Europe. The comparison for the remaining 8 EMEP stations is included in the Electronic Supplement (Fig. S3 http://www.atmos-chem-phys.net/9/ 7003/2009/acp-9-7003-2009-supplement.pdf). In all 3 simulations the modelled POA is identical; whereas SOA varies according to simulation. Clearly, differences in SOA simulations can only explain minor part of disagreements (Fig. 5). The predicted contribution of SOA to OM is large during summer: between 54\% and 77\% at the five stations of Fig. 5.

The best agreement of model and measurements is found for the Austrian station AT02, Illmitz (Fig. 5a) where observed annual averaged OM concentrations are underestimated by $40 \%$, while modelled OM concentrations are in good agreement with the observations from April to October, and strongly underestimate the winter observations. Clearly a winter source of primary or secondary organic carbon particles is missing. Similarly in Ispra (IT04, Fig. 5d) summer measurements are relatively well reproduced, while $\mathrm{OM}$ is strongly underestimated in winter. The same is found for Finokalia, a remote coastal site on Crete Island in the Eastern

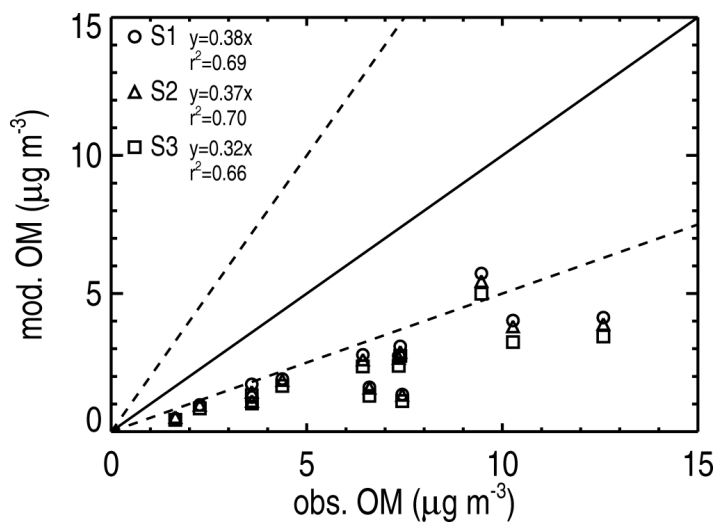

Fig. 4. Comparison of yearly averaged (July 2002 to June 2002) modelled (S1) and observed particulate organic matter (OM) for 13 surface stations during the 2002/2003 EMEP campaign on OC/EC. Measured OC concentrations were converted to OM using the station specific OM/OC ratios ranging from 1.4 to 1.8 , provided by Yttri et al. (2007). Yearly average of modelled OM is based only on those days when measurements were done at the EMEP stations. Model results from the base simulation S1 (circle), S2 (triangle) and from the simulation without SOA formation from isoprene, S3 (square).

Mediterranean which is influenced both by polluted Northeastern air and by dust transport from North Africa, showing reasonable agreement for the summer months but severe underestimation of observed $\mathrm{OM}$ during the winter months (Fig. 5f). In Portugal (PT01, Fig. 5b) modelled OM is lower than observed OM throughout the year, but similarly to Ispra and Austria the strongest underestimation is in winter (by a factor of 20). PT01 is the station with the largest discrepancy between model and observation. The yearly OM average is underestimated by a factor of 5 .

Organic aerosol at Northern European sites is expected to be dominated by biogenic SOA during summertime. A correct prediction of these sites is therefore crucial for the understanding of biogenic SOA formation. In Finland (FI17, Fig. 5c) and Sweden (SE12, Fig. 5e) OM is underestimated in all seasons, but most severely during summer. This suggests that emissions of biogenic VOC (likely terpenes) are underestimated in Northern Europe or that the currently used temperature dependence of SOA formation is inadequate. Further explanations of the discrepancies between the model and observations include the representation of SOA compounds in the currently applied two-product model, formulation of the SOA-forming reactions (mechanistic versus empirical treatment), gas phase/particle partitioning parameters (e.g. Pun et al., 2003), or the vapour pressure values (Simpson et al., 2007) that were used to derive the partitioning coefficients in this work. The latter possibility is discussed in more detail in Sect. 4.4. The underestimation of SOA thus may also be caused by too high wet scavenging of aerosols in TM5, which was previously evaluated to be relatively 

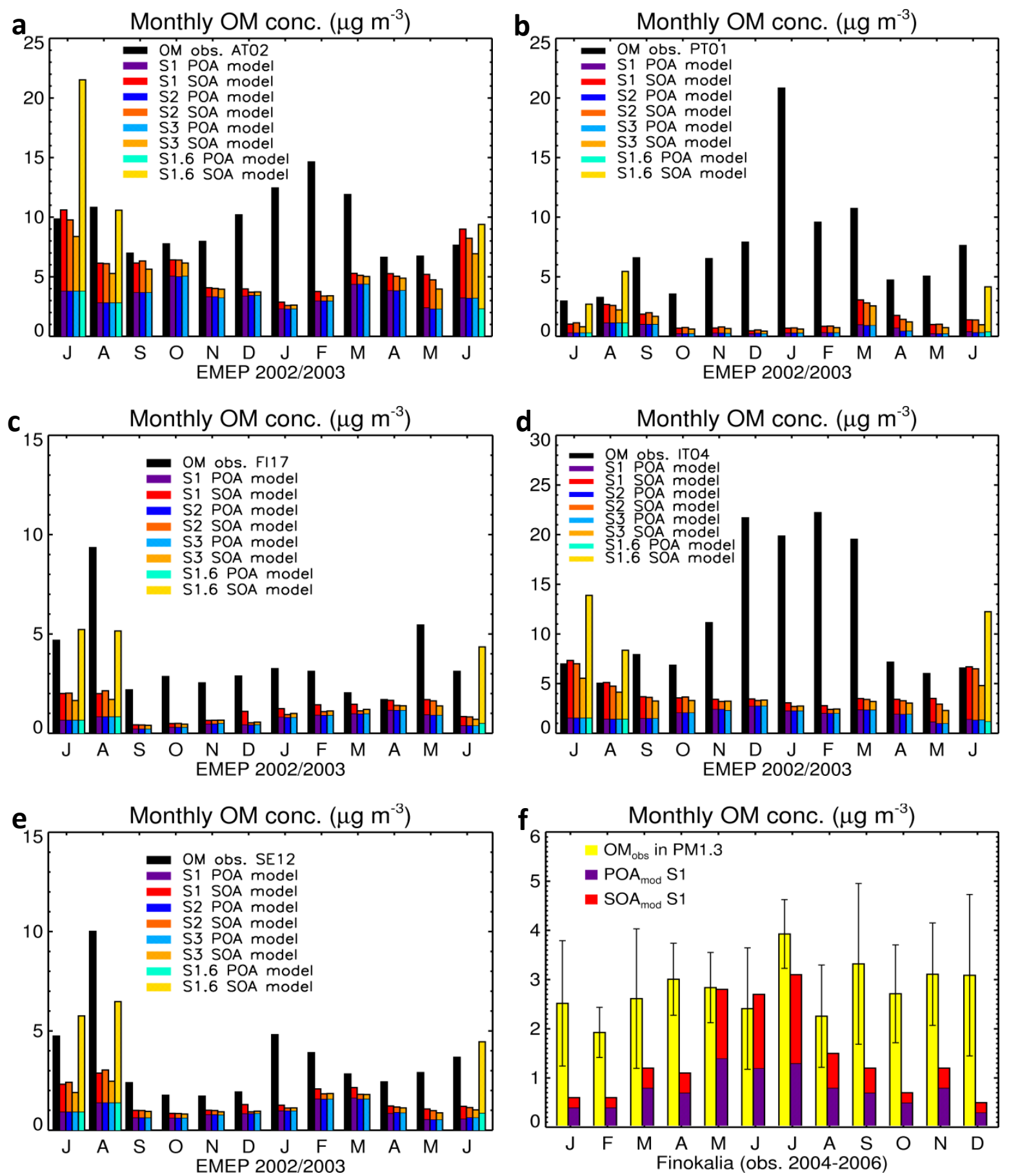

Fig. 5. Comparison of monthly averaged OM concentrations measured at 5 selected EMEP sites and at Finokalia with modelled OM concentrations. Modelled organic matter is divided into primary organic aerosol (POA) and SOA. Displayed are monthly averaged modelled concentrations from simulation S1 (purple and red bars), S2 (blue and orange bars) and S3 (light blue and light orange bars), S1.6 (cyan and yellow bars). (a) Station AT02, Illmitz, [16 $\left.46^{\prime} \mathrm{E}, 47^{\circ} 46^{\prime} \mathrm{N}\right]$ in Austria; (b) station PT01, Braganca $\left[6^{\circ} 46^{\prime} \mathrm{W}, 41^{\circ} 49^{\prime} \mathrm{N}\right]$ in Portugal. (c) station FI17, Virolathi II $\left[27^{\circ} 41^{\prime} \mathrm{E}, 60^{\circ} 32^{\prime} \mathrm{N}\right]$ in Finland. (d) station IT04, Ispra $\left[8^{\circ} 38^{\prime} \mathrm{E}, 45^{\circ} 48^{\prime} \mathrm{N}\right]$ in Northern Italy, (e) station SE12, Aspvreten $\left[17^{\circ} 23^{\prime}\right.$ E, $\left.58^{\circ} 48^{\prime} \mathrm{N}\right]$ in Sweden, (f) station Finokalia $\left[25^{\circ} 40^{\prime}\right.$ E, $\left.35^{\circ} 20^{\prime} \mathrm{N}\right]$ on Crete Island. For Finokalia, error bars denote $1-\sigma$ standard deviation and measurements are monthly OC concentration averages (in $\mathrm{PM}_{1.3}$ ) over the period July 2004 to July 2006 . Note the scale of the y-axis is not constant. S1.6 concentrations in June are from June 2002. 
efficient compared to other chemistry/transport models (Textor et al., 2006). Our maximum SOA estimate from simulation S1.6 (irreversible sticking) is in better agreement with summertime OM observations at the Scandinavian sites (denoted with cyan and yellow bars in Fig. 5), but results in an overprediction of measured OM by almost a factor of 2 in summer months at two Italian sites (IT04, IT08) and in Austria (AT02). Based on most measurements, irreversible sticking is unlikely to occur. We therefore assume other reasons for the underprediction of OM at Scandinavian sites in summer. As we found earlier in Sect. 4.1.1, our sensitivity analysis showed that using different isoprene emission inventories or different temperature and $\mathrm{NO}_{\mathrm{x}}$ dependence of isopreneSOA yields could give ca. 10-25\% lower/higher SOA concentrations in Scandinavia.

The importance of SOA derived from the oxidation of isoprene can be deduced from the difference of modelled SOA concentrations between simulation S1 and S3. Suppressing SOA formation from the isoprene oxidation decreases SOA concentrations in summer between $28 \%$ and $35 \%$ at the five stations, leading to even larger deviations of model and measurements than $\mathrm{S} 1$.

The average seasonal pattern of the modelled SOA/OM ratio for the EMEP campaign stations 2002/2003 shows a clear maximum during the summer months JJA (June to August) of 0.6-0.7, while during the winter months DJF (December to February) the fraction is lowest, $<0.3$ (Table S1 in the Electronic Supplement http://www.atmos-chem-phys. net/9/7003/2009/acp-9-7003-2009-supplement.pdf). Results from simulation S2 (Table S2, Electronic Supplement http://www.atmos-chem-phys.net/9/7003/2009/ acp-9-7003-2009-supplement.pdf) are very similar to the S1 results and modelled OM concentrations at EMEP stations are slightly lower (about 10\%) compared to S1. Excluding the formation of SOA from isoprene oxidation (S3), reduces the modelled SOA/OM ratio in summer from 0.62 to 0.54 (Table S3, Electronic Supplement http://www.atmos-chem-phys.net/9/7003/2009/ acp-9-7003-2009-supplement.pdf) and the average agreement between observed OM and modelled OM decreases by $20 \%$ for the EMEP sites.

In winter our model results indicate very little contribution from biogenic SOA since precursor emissions of terpenes and isoprene are low. The most likely cause of the winter-time discrepancy is emissions from domestic wood combustion, which is not reported in our emission database. These findings were indeed recently confirmed within the CARBOSOL project (Gelencsér et al., 2007). Wintertime residential wood burning was identified to be a significant contributor at all Carbosol sites. While our results suggest that a wintertime, likely wood burning, source is missing at all EMEP sites in Europe, the European carbonaceous aerosol model study by Simpson et al. (2007) finds no evidence of missing wood burning sources in Nordic areas.

\subsection{Comparison with global model studies}

Since a number of studies on SOA formation have been performed on the global rather than the regional scale, it is useful to compare some characteristic budget numbers of the present TM5 simulations to previous model studies. Table 6 lists global model studies that included SOAI production following the parameterisation of Henze and Seinfeld (2006). The total global production was calculated to be $33 \mathrm{Tg} \mathrm{SOA} \mathrm{yr}^{-1}$ for the reference simulation S1 (S2: $21 \mathrm{Tg} \mathrm{SOA} \mathrm{yr}^{-1}, \mathrm{~S} 3: 17 \mathrm{Tg} \mathrm{SOA} \mathrm{yr}^{-1}$; see Table 4), and lies close to the centre of the estimated range given by Kanakidou et al. (2005). Only about $1 \mathrm{Tg} \mathrm{yr}^{-1}$ of SOA-A is produced globally, but as we did not include biomass burning and biofuel emissions of aromatic hydrocarbons, the actual produced anthropogenic SOA may be underestimated by a factor of two or higher (Henze et al., 2008). Our base result is higher than the global SOA estimate given by Henze and Seinfeld (2006) of about $16 \mathrm{Tg} \mathrm{yr}^{-1}$, but lower than the estimate of $55 \mathrm{Tg} \mathrm{yr}^{-1}$ from the Oslo CTM2 global model by Hoyle et al. (2007). The discrepancy between TM5 and Oslo CTM2 is surprising, since both models use ECMWF meteorological data and POC emissions from Bond et al. (2004). In addition global isoprene emissions used in Oslo CTM2 are roughly a factor of two lower than in TM5.

The annual mean global SOA burden for the year $2002 / 2003$ was found to be $230 \mathrm{Gg}$ of biogenic SOA and $5 \mathrm{Gg}$ of anthropogenic SOA, respectively. SOA derived from isoprene oxidation has a global annual burden of $120 \mathrm{Gg}$ in our base simulation. This number is $50 \%$ higher than the global SOA-I burden of $80 \mathrm{Gg}$ in present-day simulations with TM3 (Tsigaridis and Kanakidou, 2007). Our global biogenic SOA burden is lower than the estimate from Henze and Seinfeld (2006) of about $390 \mathrm{Gg}$, which can probably be explained by a more efficient wet scavenging of aerosols in TM5. The global biogenic SOA burden in our simulation S3 (excluding SOA-I) is $109 \mathrm{Gg}$ and is similar to the result from TM3 simulations by Tsigaridis and Kanakidou (2003) (their simulation S1.1: $116 \mathrm{Gg}$ ), which did not consider SOA-I formation.

The global production of SOA-I is $15 \mathrm{Tg} \mathrm{yr}^{-1}$ in the S1 simulation with TM5. Previous estimates of the global SOA-I production using the two-product scheme for isoprene range from roughly 5 to $15 \mathrm{Tg} \mathrm{yr}^{-1}$. Simulations of Tsigaridis and Kanakidou (2007) with TM3 resulted in a present-day isoprene oxidation production of 4.6 $\mathrm{Tg} \mathrm{SOA} \mathrm{yr}^{-1}$ which is a factor 3 lower than our S1 result but similar to our S2 result of $3.2 \mathrm{Tg} \mathrm{yr}^{-1}$ SOA-I. The smaller SOA-I production in $\mathrm{S} 2$ can be attributed to reduced isoprene emissions from the MEGAN inventory, the $\mathrm{NO}_{\mathrm{x}}$ dependence of the partitioning and wet deposition of isoprene oxidation products.

Henze and Seinfeld (2006) obtained a global production of $6 \mathrm{Tg} \mathrm{yr}^{-1}$ isoprene SOA with the GEOS-Chem model. Since isoprene emissions in GEOS-Chem are around $500 \mathrm{Tg} \mathrm{yr}^{-1}$ 
Table 6. Comparison of global model studies including SOA formation from isoprene photo-oxidation. In all listed studies, isoprene SOA parameterisation follows the approach of Henze and Seinfeld (2006).

\begin{tabular}{|c|c|c|c|c|}
\hline Reference & Model & $\begin{array}{l}\text { Domain and } \\
\text { resolution }\end{array}$ & $\begin{array}{c}\text { Prod. SOA } \\
\left(\mathrm{Tg} \mathrm{yr}^{-1}\right)\end{array}$ & $\begin{array}{c}\text { Prod. SOA-I } \\
\left(\mathrm{Tg} \mathrm{yr}^{-1}\right)\end{array}$ \\
\hline Henze and Seinfeld (2006) & GEOS-Chem & global, $4^{\circ} \times 5^{\circ}$ & 16.4 & 6.2 \\
\hline Tsigaridis and Kanakidou (2007) a,b & TM3 & global, $3.75^{\circ} \times 5^{\circ}$ & 18.6 & 4.6 \\
\hline Hoyle et al. (2007) & Oslo CTM2 & global, $2.8^{\circ} \times 2.8^{\circ}$ & 55 & 15 \\
\hline Henze et al. (2008) & GEOS-Chem & global, $2^{\circ} \times 2.5^{\circ}$ & 30 & 14.4 \\
\hline This work, S1 & TM5 & global, $6^{\circ} \times 4^{\circ}$ & 33 & 15 \\
\hline This work, $\mathrm{S} 2 \mathrm{a}^{\mathrm{a}}$ & TM5 & global, $6^{\circ} \times 4^{\circ}$ & 21 & 3.2 \\
\hline
\end{tabular}

\footnotetext{
a Dependence of SOA-I production on $\mathrm{VOC} / \mathrm{NO}_{\mathrm{x}}$ ratio is taken into account.

$\mathrm{b}$ Present day simulation.
}

and thus comparable with our simulation S1, different transport parameterisations of SOA precursors and aerosols or the effect of removal efficiency, pre-existing aerosol and $\mathrm{OH}$ levels may be the cause for this discrepancy. An indication for the latter is that the global reaction rate of isoprene with $\mathrm{OH}$ is around $300 \mathrm{Tg} \mathrm{yr}^{-1}$ in TM5 and only $209 \mathrm{Tg} \mathrm{yr}^{-1}$ in the simulations of Henze and Seinfeld (2006). We note that the $\mathrm{OH}$ fields in this study would give a tropospheric (surface to $100 \mathrm{hPa}$ ) methane lifetime of 7.3 years. Apart from $\mathrm{OH}$ fields, different removal efficiencies and levels of primary carbonaceous aerosol are a likely cause for the discrepancy.

\subsection{Comparison with a regional model study}

Significant underestimation of wintertime organic matter is in line with the model study of Simpson et al. (2007), who used the EMEP MSC-W regional 3-d model to study the formation of carbonaceous aerosol over Europe during the EMEP 2002/2003 campaign. In their SOA module (Kam-2), monoterpenes are only represented by $\alpha$-pinene, which is the currently best understood single monoterpene, while isoprene and sesquiterpenes are not considered as SOA precursors in their model. With Kam-2 Simpson et al. (2007) underpredicted the measured total carbon levels in Northern Europe by a factor of 2 . When using a SOA module with increased SOA partitioning coefficients (Kam-2X) instead, the agreement at Scandinavian sites was significantly improved. However, like in this study, their model underpredicted total carbon levels over Southern Europe especially during winter. They suggested a large impact of a wood burning source of primary carbonaceous particles at a site in Portugal (Aveiro) and other sites in Southern and Eastern Europe, using Levoglucosan measurements as an indicator for wood burning source of organic aerosol. Their model results of total carbon with an assumed additional wood burning source were closer to the observed total carbon levels.

It can be concluded, that the POC emission inventory for fossil fuel and biofuel combustion applied in this study (Bond et al., 2004) severely underestimates wood burning
POC emissions. The recent European inventory of Kupiainen and Klimont (2007) which considers country-specific emission characteristics represents the residential wood combustion by a number of source categories, e.g. fireplaces, stoves, single house boilers, and medium size boilers. These authors find that residential wood combustion contributes about $50 \%$ and $65 \%$ to the emitted POC in Western and Eastern Europe, respectively. From 1990 to 2000 the contribution from biomass burning to $\mathrm{BC}$ and $\mathrm{POC}$ emissions continuously increased.

However, we cannot exclude that secondary organic aerosol formation can explain the missing winter source of particulate organic matter, but since vegetation emissions are extremely low in winter, this source should be of anthropogenic origin. Predicted SOA-A surface concentrations over Europe with a revised production scheme for aromatics (Henze et al., 2008) are actually largest during summer (about $0.1 \mu \mathrm{g} \mathrm{m}^{-3}$ ) and very low during winter, rendering the anthropogenic SOA contribution an unlikely explanation for the winter-time discrepancy.

Forest and agricultural fires can be important during summer in Southern Europe. Including open vegetation fire OC emissions could improve the agreement with observations in particular at sites in Portugal (Simpson et al., 2007).

Sampling and subsequent analysis of the aerosol OC content are subject to great uncertainties. This is attributed to adsorption and evaporation of semi volatile organic constituents to the filter during sampling, which can cause severe positive and negative artefacts on the true particulate OC loading. Data compiled by Yttri et al. (2007) show that the positive sampling artefact of OC can vary between 6 and 30\% for European measurement sites of various site categories, which would bring model and measurements in slightly better agreement for the current study. On the other hand, the magnitude of the negative artefacts could be equally large, making any such assumption highly speculative. 


\section{Conclusions}

This model study assessed in a systematic way various uncertainties in the global modelling of secondary organic aerosol formation with a focus on Europe. Specifically, we considered uncertainties in isoprene emissions, the $\mathrm{NO}_{\mathrm{x}}$ dependent chemistry of isoprene SOA formation, the wet removal, and the role of absorbing aerosol.

Monthly averaged SOA surface concentrations range from 0.6 to $6.8 \mu \mathrm{g} \mathrm{m}^{-3}$ over continental Europe during summer in our reference simulation. In sensitivity studies on SOA parameterisations it was found that surface concentrations vary by $\pm 30 \%$ for most cases. The parameterisations are most sensitive for the assumption whether inorganic aerosol could act as an SOA absorber, and whether or not irreversible sticking of SOA takes place. Changes in the emissions of isoprene have a limited effect on SOA production rates over Europe (20-30\%, Table 5). Using the recent MEGAN isoprene emission inventory and emission parameterisation decreases SOA surface concentrations by on average $20 \%$ in Europe. SOA concentrations in summer increased over urban and industrialised regions by $10-20 \%$ when the $\mathrm{NO}_{\mathrm{x}}$ dependence of the SOA yield from isoprene oxidation was taken into account. Under low $\mathrm{VOC} / \mathrm{NO}_{\mathrm{x}}$ conditions typical for urban regions, a higher yield of relatively volatile gasphase products are formed in the isoprene oxidation than under high VOC/NO $\mathrm{x}_{\mathrm{x}}$ conditions. Due to high load of primary carbonaceous aerosols over cities and industrial areas these more volatile vapours are absorbed effectively.

We further analysed in depth three simulations: our reference simulation $\mathrm{S} 1$, which is similar to the study by Tsigaridis and Kanakidou (2003) (their simulation S1.1), S2 which considered several updates in parameterisations and S3 which ignored isoprene SOA formation.

There are only few field measurements of particle phase isoprene oxidation products available for Europe. Since isoprene oxidation likely leads to a large fraction of humiclike substances, particle phase isoprene oxidation products like 2-methylglyceric acid and tetrols should be viewed as marker compounds for SOA from isoprene photo-oxidation and not as total SOA-I. Thus currently, measurements of these marker compounds cannot be used to constrain modelled SOA formation from isoprene.

Comparison of model results from S1, S2, and S3 with EMEP field data obtained in 2002/2003 showed that general agreement with summer OM was reached, whereas winter OM was strongly underpredicted. Simulations S1 and S2 are in slightly better agreement than our simulation S3 that ignored an isoprene-SOA source. The main fraction of organic aerosol observed at the EMEP sites during summer is predicted to be secondary and of biogenic origin. This is the consequence of the high production of SOA from precursors emitted by the vegetation in summer. Though lower temperatures favour the formation of SOA in the atmosphere, the decreasing amount of condensable gases from biogenic origin strongly reduces formation of biogenic SOA in winter. According to the model results (S1-S3), biogenic SOA constitutes only a minor fraction of OM during winter (December to February). Focusing on the summer months, one may conclude that in general SOA produced from biogenic emissions brings observations and measurements in better agreement.

Underestimation of SOA at Scandinavian EMEP sites during summer in our study (simulations S1-S3) could be an indication for missing biogenic VOC sources in this region, an incorrect implementation of temperature dependence of SOA partitioning, and/or transformation of condensable products by reaction on particles. There is experimental evidence for the transformation of condensed vapour (e.g. pinonaldehyde) into a non-volatile SOA compound by reaction in the particle phase (Kamens and Jaoui, 2001; Iinuma et al., 2004; Kroll et al., 2007), suggesting irreversible sticking on particles. The agreement with OM observations at Scandinavian sites in summer indeed largely improves when condensation on inorganic aerosols and irreversible sticking of SOA-precursors on particles is taken into account (simulation S1.6). However, the comparison with OM measurements in Italy and Austria contradicts this hypothesis. The exact mechanisms of the oligomer and/or polymer formation and their significance for the chemical formation and properties of SOA remain highly uncertain. Oligomerisation can be separated into fast and slow processes. While the fast oligomerisation is probably implicitly included in the two product parameterisation, slow oligomerization occurs on a time scale relevant to atmospheric transport and is difficult to represent in models. Slow oligomerization may occur through several particlephase processes like acid-catalyzed heterogeneous reactions, oxidative processes and accretion reactions (Kroll and Seinfeld, 2008) making any generalized representation in models highly uncertain. Our sensitivity case S1.6 can provide an upper limit for estimating the effect of irreversible chemical transformation, e.g. through oligomerisation, and/or physical trapping of condensing vapours.

Missing primary, wood-burning, organic particle sources in winter, are the most likely explanation for the wintertime discrepancy, whereas missing anthropogenic SOA sources seem less probable. Uncertainties associated with carbonaceous aerosol emission inventories prevent a further improvement of SOA predictions in Europe. Therefore, more work should be devoted to compile accurate European emission inventories of primary carbonaceous particles since their distribution and magnitude is of decisive importance for understanding the distribution of SOA over Europe.

Global tropospheric SOA production is calculated to be $33 \mathrm{Tg} \mathrm{yr}^{-1}$ in S1 (reference simulation), $21 \mathrm{Tg} \mathrm{yr}^{-1}$ in $\mathrm{S} 2$ (best guess simulation), and $17 \mathrm{Tg} \mathrm{yr}^{-1}$ in $\mathrm{S} 3$, the difference with $\mathrm{S} 1$ is a measure for the amount of SOA produced by isoprene oxidation. The result from the reference simulation is close to the centre of the estimated range given by Kanakidou et al. (2005). Ignoring SOA from isoprene, lowers tropospheric SOA production and burden over Europe in 
JJA 2002 by $42 \%$ and $44 \%$ and surface concentrations by 30 $50 \%$ compared to $\mathrm{S} 1$, respectively. In the troposphere over Europe the SOA production is $1.0 \mathrm{Tg} \mathrm{yr}^{-1}$ in $\mathrm{S} 1,0.7 \mathrm{Tg} \mathrm{yr}^{-1}$ in $\mathrm{S} 2$ and $0.5 \mathrm{Tg} \mathrm{yr}^{-1}$ in $\mathrm{S} 3$.

The export of SOA produced in the troposphere over Europe ( $\mathrm{S} 1: 0.21 \mathrm{Tg} \mathrm{yr}^{-1}$ ) constitutes a substantial contribution to the carbonaceous aerosols that are transported from $\mathrm{Eu}-$ rope to other world regions. A fraction of $35 \%$ of the SOA produced in the European PBL is transported to higher altitudes or out of Europe. The vertical transport of SOA particles to higher altitudes over Europe is only $14 \%$ of the amount that is directly produced in the atmosphere at high altitudes due to condensation of uplifted gaseous oxidation products on particles at low temperatures.

Model studies demonstrate the large potential impact of the partitioning of SOA to inorganic aerosols on global SOA production (Tsigaridis and Kanakidou, 2003; Hoyle et al., 2007). For example, Tsigaridis and Kanakidou (2003) found a $87 \%$ increase of the global SOA production by allowing semi-volatile species to partition to sulphuric and ammonium aerosols in addition to their partitioning to carbonaceous aerosols. It can however be argued that in the real atmosphere, inorganic aerosol will in many cases be deliquescent, with water attached to the particles. Consequently, inorganic and organic compounds will be partly or completely dissolved and dissociated in the water phase. In atmospheric models this is often handled by phase separation into a hydrophilic phase containing the inorganic salt in aqueous solution and into a hydrophobic phase comprising the organic components (e.g. Pun et al., 2002; Griffin et al., 2003; Clegg et al., 2008). However, in principle all compounds may be present to some degree in both phases. Treatment of SOA partitioning to inorganic aerosols in models is still limited by the paucity of thermodynamic data on mixtures of organic and inorganic species of atmospheric interest. In this study, liquid water has been assumed not to affect the partitioning of semi-volatile organic compounds.

Inclusion of the most recent insights in the isoprene SOA formation mechanism in simulation S2 reduces the tropospheric production of SOA from isoprene oxidation globally from $15 \mathrm{Tg} \mathrm{yr}^{-1}$ (in S1) to $3.2 \mathrm{Tg} \mathrm{yr}^{-1}$ and over Europe from $0.4 \mathrm{Tg} \mathrm{yr}^{-1}$ (in S1) to $0.1 \mathrm{Tg} \mathrm{yr}^{-1}$. At the same time, summertime surface concentrations of total SOA in Europe decrease by up to $40 \%$ compared to our reference simulation. Using this updated parameterisation without condensation of semi-volatile oxidation products on ammonium and sulphate aerosols (S2.1) results in a tropospheric production of isoprene SOA that is by a factor of ten smaller compared to S1 and the contribution of isoprene oxidation to the total SOA production becomes negligible.

To elucidate the nature of the absorption process of organic vapours into inorganic aerosols or mixed inorganic/organic aerosols we propose to perform chamber experiments at low, i.e. close to atmospheric, concentrations of the precursor VOC. The precursor's concentration should be below the threshold for self-nucleation of the organic to avoid new particle formation. A series of experiments should be performed at comparable initial concentrations of reactants in a dry chamber with 1) no seed initially present, 2) inorganic seed (with varying acidity), and 3 ) mixed inorganic/organic seed (with varying proportions). The first experiment series targets at finding the adequate precursor concentration, at which self-nucleation is disabled, for all the following experiments. It is expected that no SOA can form in this experiment. The second experiment series aims at investigating the effect of the presence inorganic particle and particle acidity on SOA partitioning. Finding substantial SOA yields in these experiments would confirm the atmospheric relevance of the absorption into inorganic particles. The third experiment series is done to quantify the compositional effect on SOA partitioning.

Our study provides a systematic benchmark on the impact of various new insights in the formation of SOA from isoprene, and allows understanding them in the context of previous studies, and recent organic aerosol measurements. Most urgent work to better understand the role of isoprene and other biogenic precursor gases in the formation of SOA includes the improvement of current emission inventories (BVOC and BC/POC), and experimental studies on condensation behaviour, heterogeneous reactions and oligomerisation.

Acknowledgements. We would like to thank Arjo Segers and Maarten Krol for support with TM5, Bruno Guillaume and Cathy Liousse for providing the European $\mathrm{BC} / \mathrm{OC}_{p}$ inventory, Maria Kanakidou and Nikos Mihalopoulos for the Finokalia OC data, and Laurens Ganzeveld for the radiation code. Kostas Tsigaridis was supported by an appointment to the NASA Postdoctoral Program at the Goddard Institute for Space Studies, administered by Oak Ridge Associated Universities through a contract with NASA.

Edited by: S. Pandis

\section{References}

Altieri, K. E., Carlton, A. G., Turpin, B. J., and Seitzinger, S.: Formation of oligomers in cloud-processing: Reactions of isoprene oxidation products, Environ. Sci. Technol., 40, 4956-4960, 2006.

Altieri, K. E., Seitzinger, S. P., Carlton, A. G., Turpin, B. J., Klein, G. C., and Marshall, A. G.: Oligomers formed through in-cloud methylglyoxal reactions: chemical composition, properties, and mechanisms investigated by ultra-high resolution FT-ICR mass spectrometry, Atmos. Environ., 42, 1476-1490, doi:1410.1016/j.atmosenv.2007.1411.1015, 2008.

Bergamaschi, P., Meirink, J. F., Müller, J. F., Körner, S., Heimann, M., Bousquet, P., Dlugokencky, E. J., Kaminski, U., Vecchi, R., Marcazzan, G., Meinhardt, F., Ramonet, M., Sartorius, H., and Zahorowski, W.: Model Inter-comparison on Transport and Chemistry - report on model inter-comparison performed within European Commission FP5 project EVERGREEN (Global satellite observation of greenhouse gas emissions) EUR 22241 EN- 
DG Joint Research Centre, Institute for Environment and Sustainability, Scientific and Technical Research series, ISBN 9279-02001-3, 53 pp., EUR 22241 EN, 2006.

Bond, T. C., Streets, D. G., Yarber, K. F., Nelson, S. M., Woo, J.H., and Klimont, Z.: A technology-based global inventory of black and organic carbon emissions from combustion, J. Geophys. Res., 109, D14203, doi:10.1029/2003JD003697, 2004.

Bowman, F. M. and Karamalegos, A. M.: Estimated effects of composition on secondary organic aerosol mass concentrations, Environ. Sci. Technol., 36, 2701-2707, 2002.

Böge, O., Miao, Y., Plewka, A., and Herrmann, H.: Formation of secondary organic particle phase compounds from isoprene gasphase oxidation products: An aerosol chamber and field study, Atmos. Environ., 40, 2501-2509, 2006.

Capouet, M., Müller, J.-F., Ceulemans, K., Compernolle, S. Vereecken, L., and Peeters, J.: Modeling aerosol formation in alpha-pinene photo-oxidation experiments, J. Geophys. Res., 113, D02308, doi:10.1029/2007JD008995, 2008.

Carlton, A. G., Turpin, B. J., Altieri, K. E., Reff, A., Seitzinger, S., Lim, H. J., and Ervens, B.: Atmospheric oxalic acid and SOA production from glyoxal: Results of aqueous photooxidation experiments, Atmos. Environ., 41, 7588-7602, 2007.

Carlton, A. G., Wiedinmyer, C. and Kroll, J. H.: A review of Secondary Organic Aerosol (SOA) formation from isoprene, Atmos. Chem. Phys., 9, 4987-5005, 2009,

http://www.atmos-chem-phys.net/9/4987/2009/.

Chung, S. H. and Seinfeld, J. H.: Global distribution and climate forcing of carbonaceous aerosols, J. Geophys. Res., 107(D19), 4407, doi:10.1029/2001JD001397, 2002.

Claeys, M., Graham, B., Vas, G., Wang, W., Vermeylen, R., Pashynska, V., Cafmeyer, J., Guyon, P., Andreae, M. O., Artaxo, P., and Maenhaut, W.: Formation of secondary organic aerosols through photooxidation of isoprene, Science, 303, 1173-1176, 2004a.

Claeys, M., Wang, W., Ion, A. C., Kourtchev, I., Gelencsér, A., and Maenhaut, W.: Formation of secondary organic aerosols from isoprene and its gas-phase oxidation products through reaction with hydrogen peroxide, Atmos. Environ., 38, 4093-4098, 2004b.

Clegg, S. L., Kleeman, M. J., Griffin, R. J., and Seinfeld, J. H.: Effects of uncertainties in the thermodynamic properties of aerosol components in an air quality model - Part 1: Treatment of inorganic electrolytes and organic compounds in the condensed phase, Atmos. Chem. Phys., 8, 1057-1085, 2008, http://www.atmos-chem-phys.net/8/1057/2008/.

Cocker, D. R. III, Clegg, S. L., Flagan, R. C., and Seinfeld, J. H.: The effect of water on gas-particle partitioning of secondary organic aerosol. Part I: $\alpha$-pinene/ozone system, Atmos. Environ., 35, 6049-6072, 2001.

Cooke, W. F. and Wilson, J. J. N.: A global black carbon aerosol model, J. Geophys. Res., 101(D14), 19395-19409, 1996.

Crutzen, P. J. and Lawrence, M. G.: The impact of precipitation scavenging on the transport of trace gases: A 3-dimensional model sensitivity study, J. Atmos. Chem., 37, 81-112, 2000.

Czoschke, N. M. and Jang, M.: Acidity effects on the formation of $\alpha$-pinene ozone SOA in the presence of inorganic seed, Atmos. Environ., 40, 4370-4380, 2006.

Czoschke, N. M., Jang, M., and Kamens, R. M.: Effect of acidic seed on biogenic secondary organic aerosol growth, Atmos. Environ., 37, 4287-4299, 2003.
De Meij A., Krol, M., Dentener, F., Vignati, E., Cuvelier, C., and Thunis, P.: The sensitivity of aerosol in Europe to two different emission inventories and temporal distribution of emissions, Atmos. Chem. Phys., 6, 4287-4309, 2006,

http://www.atmos-chem-phys.net/6/4287/2006/.

Dentener, F., Kinne, S., Bond, T., Boucher, O., Cofala, J., Generoso, S., Ginoux, P., Gong, S., Hoelzemann, J. J., Ito, A., Marelli, L., Penner, J. E., Putaud, J.-P., Textor, C., Schulz, M., van der Werf, G. R., and Wilson, J.: Emissions of primary aerosol and precursor gases in the years 2000 and 1750 prescribed data-sets for AeroCom, Atmos. Chem. Phys., 6, 4321-4344, 2006, http://www.atmos-chem-phys.net/6/4321/2006/.

Donahue, N. M., Robinson, A. L., Stanier, C. O., and Pandis, S. N.: Coupled partitioning, dilution, and chemical aging of semivolatile organics, Environ. Sci. Technol., 40, 2635-2643, 2006.

Donahue, N. M., Robinson, A. L., and Pandis, S. N.: Atmospheric organic particulate matter: From smoke to secondary organic aerosol, Atmos. Environ., 43, 94-106, 2009.

Edney, E. O., Kleindienst, T. E., Jaoui, M., Lewandowski, M., Offenberg, J. H., Wang, W., and Claeys, M.: Formation of 2-methyl tetrols and 2-methylglyceric acid in secondary organic aerosol from laboratory irradiated isoprene/ $\mathrm{NO}_{\mathrm{X}} / \mathrm{SO}_{2}$ /air mixtures and their detection in ambient $\mathrm{PM}_{2.5}$ samples in the eastern United States, Atmos. Environ., 39, 5281-5289, 2005.

EMEP, Convention on Long-Range Transboundary Air Pollution, VOC data online, http://www.nilu.no/projects/ccc/emepdata. html, 2008.

Ervens, B., Feingold, G., Frost, G. J., and Kreidenweis, S. M.: A modeling study of aqueous production of dicarboxylic acids: 1. Chemical pathways and speciated organic mass production, J. Geophys. Res., 109, D15205, doi:10.1029/2003JD004387, 2004.

Ervens, B., Carlton, A. G., Turpin, B. J., Altieri, K. E., Kreidenweis, S. M., and Feingold, G.: Secondary organic aerosol yields from cloud-processing of isoprene oxidation products, Geophys. Res. Lett., 35, L02816, doi:10.1029/2007GL031828, 2008.

Fu, T. M., Jacob, D. J., Wittrock, F., Burrows, J. P., Vrekoussis, M., and Henze, D. K.: Global budgets of atmospheric glyoxal and methylglyoxal, and implications for formation of secondary organic aerosols, J. Geophys. Res., 113, D151303, doi:10.1029/2007JD009505, 2008.

Ganzeveld, L. and Lelieveld, J.: Dry deposition parameterization in a chemical general circulation model and its influence on the distribution of reactive trace gases, J. Geophys. Res., 100, 20999 21012, 1995

Gelencsér, A., May, B., Simpson, D., Sánchez-Ochoa, A., Kasper-Giebl, A., Puxbaum, H., Caseiro, A., Pio, C., and Legrand, M.: Source apportionment of $\mathrm{PM}_{2.5}$ organic aerosol over Europe: Primary/secondary, natural/anthropogenic, and fossil/biogenic origin, J. Geophys. Res., 112, D23S04, doi:10.1029/2006JD008094, 2007.

Gery M. W., Whitten G. Z., and Killus, J. P.: Development and testing of the CBM-IV for urban and regional modelling, EPA600/3-88-012. US EPA, Research Triangle Park, 1989a.

Gery, M. W., Whitten, G. Z., Killus, J. P., and Dodge, M. C.: A photochemical kinetics mechanism for urban and regional scale computer modeling, J. Geophys. Res., 94D, 12925-12956, 1989b. 
Goldstein, A. H. and Galbally, I. E.: Known and unexplored organic constituents in the Earth's atmosphere, Environ. Sci. Technol., 41, 1541-1531, 2007.

Gómez-González, Y., Surratt, J. D., Cuyckens, F., Szmigielski, R., Vermeylen, R., Jaoui, M., Lewandowski, M., Offenberg, J. H., Kleindienst, T. E., Edney, E. O., Blockhuys, F., Van Alsenoy, C., Maenhaut, W., and Claeys, M.: Characterization of organosulphates from the photooxidation of isoprene and unsaturated fatty acids in ambient aerosol using liquid chromatography/(-) electrospray ionization mass spectrometry, J. Mass. Spectrom., 43, 371-382, 2008.

Griffin, R. J., Cocker III, D. R., Flagan, R. C., and Seinfeld, J. H.: Organic aerosol formation from the oxidation of biogenic hydrocarbons, J. Geophys. Res., 104(D3), 3555-3567, 1999a.

Griffin, R. J., Cocker III, D. R., Seinfeld, J. H., and Dabdub, D.: Estimate of global atmospheric organic aerosol from oxidation of biogenic hydrocarbons, Geophys. Res. Lett., 26(17), 27212724, 1999b.

Griffin, R. J., Nguyen, K., Dabdub, D., and Seinfeld, J. H.: A coupled hydrophobic-hydrophilic model for predicting secondary organic aerosol formation, J. Atmos. Chem., 44, 171-190, 2003.

Guelle, W., Balkanski, Y. J., Schultz, M., Dulac, F., and Monfray, P.: Wet deposition in a global size-dependent aerosol transport model, 1. Comparison with 1 year ${ }^{210} \mathrm{~Pb}$ simulation with ground measurements, J. Geophys. Res., 103, 11429-11445, 1998.

Guenther, A.: Seasonal and spatial variations in natural volatile organic compound emissions, Ecol. Appl., 7, 34-45, 1997.

Guenther, A., Zimmerman, P., Harley, P., Monson, R. K., and Fall, R.: Isoprene and monoterpene emission rate variability: Model evaluation and sensitivity analyses, J. Geophys. Res., 98(D7), 12609-12617, 1993.

Guenther, A., Hewitt, C. N., Erickson, D., Fall, R., Geron, C., Graedel, T., Harley, P., Klinger, L., Lerdau, M., McKay, W. A., Pierce, T., Scholes, B., Steinbrecher, R., Tallamraju, R., Taylor, J., and Zimmerman, P.: A global model of natural volatile organic compound emissions, J. Geophys. Res., 100, 9973-8892, 1995.

Guenther, A., Karl, T., Harley, P., Wiedinmyer, C., Palmer, P. I., and Geron, C.: Estimates of global terrestrial isoprene emissions using MEGAN (Model of Emissions of Gases and Aerosols from Nature), Atmos. Chem. Phys., 6, 3181-3210, 2006,

http://www.atmos-chem-phys.net/6/3181/2006/.

Guillaume, B. and Liousse, C.: Development of carbonaceous aerosol emission inventories from fossil fuel over Europe at continental scale with focus on traffic at national and regional scales, ADEME (French Ministry of Environment and Sustainable Development) Report, Project 0262050, 2004.

Hallquist, M., Wenger, J. C., Baltensperger, U., Rudich, Y., Simpson, D., Claeys, M., Dommen, J., Donahue, N. M., George, C., Goldstein, A. H., Hamilton, J. F., Herrmann, H., Hoffmann, T., Iinuma, Y., Jang, M., Jenkin, M., Jimenez, J. L., Kiendler-Scharr, A., Maenhaut, W., McFiggans, G., Mentel, Th. F., Monod, A., Prévôt, A. S. H., Seinfeld, S. H., Surratt, J. D., Szmigielski, R., and Wildt, J.: The formation, properties and impact of secondary organic aerosol: current and emerging issues, Atmos. Chem. Phys., 9, 5155-5235, 2009,

http://www.atmos-chem-phys.net/9/5155/2009/.

Heaton, K. J., Dreyfus, M. A., Wang, S., and Johnston, M. V.:
Oligomers in the early stage of biogenic secondary organic aerosol formation and growth, Environ. Sci. Technol., 41, 61296136, 2007.

Henze, D. K. and Seinfeld, J. H.: Global secondary organic aerosol from isoprene oxidation, Geophys. Res. Lett., 33, L09812, doi:10.1029/2006GL025976, 2006.

Henze, D. K., Seinfeld, J. H., Ng, N. L., Kroll, J. H., Fu, T.-M., Jacob, D. J., and Heald, C. L.: Global modeling of secondary organic aerosol formation from aromatic hydrocarbons: highvs. low-yield pathways, Atmos. Chem. Phys., 8, 2405-2420, 2008 , http://www.atmos-chem-phys.net/8/2405/2008/.

Herrmann, H., Tilgner, A., Barzaghi, P., Majdik, Z., Gligorovski, S., Poulain, L., and Monod, A.: Towards a more detailed description of tropospheric aqueous phase organic chemistry: CAPRAM3.0, Atmos. Environ., 39(23-24), 4351-4363, 2005.

Hertel, O., Berkowicz, R., and Christensen, J.: Test of two numerical schemes for use in atmospheric transport-chemistry models, Atmos. Environ., 27A(16), 2591-2611, 1993.

Hoffmann, T., Odum, J. R., Bowman, F., Collins, D., Klockow, D., Flagan, R. C., and Seinfeld, J. H.: Formation of organic aerosol from the oxidation of biogenic hydrocarbons, J. Atmos. Chem., 26, 189-222, 1997.

Hoffmann, T., Bandur, R., Marggraf, U., and Linscheid, M.: Molecular composition of organic aerosol formed in the $\alpha$-pinene/ $\mathrm{O}_{3}$ reaction: Implications for new particle formation, J. Geophys. Res., 103(D19), 25569-25578, 1998.

Holtslag, A. A. M. and Moeng, C.-H.: Eddy diffusivity and countergradient transport in the convective atmospheric boundary layer, J. Atmos. Sci., 48, 1690-1698, 1991.

Houweling, S., Dentener, F., and Lelieveld, J.: The impact of nonmethane hydrocarbon compounds on tropospheric photochemistry, J. Geophys. Res., 103, 10637-10696, 1998.

Hoyle, C. R., Berntsen, T., Myhre, G., and Isaksen, I. S. A.: Secondary organic aerosol in the global aerosol - chemical transport model Oslo CTM2, Atmos. Chem. Phys., 7, 5675-5694, 2007, http://www.atmos-chem-phys.net/7/5675/2007/.

Iinuma, Y., Böge, O., Gnauk, T., and Herrmann, H.: Aerosolchamber study of the $\alpha$-pinene $/ \mathrm{O}_{3}$ reaction: influence of particle acidity on aerosol yields and products, Atmos. Environ., 38, 761-773, 2004.

Ion, A. C., Vermeylen, R., Kourtchev, I., Cafmeyer, J., Chi, X., Gelencsér, A., Maenhaut, W., and Claeys, M.: Polar organic compounds in rural $\mathrm{PM}_{2.5}$ aerosols from K-puszta, Hungary, during a 2003 summer field campaign: Sources and diel variations, Atmos. Chem. Phys., 5, 1805-1814, 2005,

http://www.atmos-chem-phys.net/5/1805/2005/.

Jang, M. and Kamens, R. M.: A thermodynamic approach for modeling partitioning of SOCs on atmospheric particulate matter: humidity effects, Environ. Sci. Technol., 32, 1237-1243, 1998.

Jang, M. and Kamens, R. M.: Atmospheric secondary aerosol formation by heterogeneous reactions of aldehydes in the presence of a sulphuric acid aerosol catalyst, Environ. Sci. Technol., 35, 4758-4766, 2001.

Jang, M., Czoschke, N. M., Lee, S., and Kamens, R. M.: Aerosol production by acid-catalyzed particle-phase reactions, Science, 298, 814-817, 2002.

Jang, M., Carroll, B., Chandramouli, B., and Kamens, R. M.: Particle growth by acid-catalyzed heterogeneous reactions of organic 
carbonyls on pre-existing aerosol, Environ. Sci. Technol., 37, 3828-3837, 2003.

Jang, M., Czoschke, N. M., Northcross, A. L., Cao, G., and Shaof, D.: SOA formation from partitioning and heterogeneous reactions: Model study in the presence of inorganic species, Environ. Sci. Technol., 40, 3013-3022, 2006.

Jeuken, A., Veefkind, P., Dentener, F., Metzger, S., and RoblesGonzalez, C.: Simulation of the aerosol optical depth over Europe for August 1997 and a comparison with observations, J. Geophys. Res., 106, 28295-28311, 2001.

Junker, C. and Liousse, C.: A global emission inventory of carbonaceous aerosol from historic records of fossil fuel and biofuel consumption for the period 1860-1997, Atmos. Chem. Phys., 8, 1195-1207, 2008, http://www.atmos-chem-phys.net/8/1195/2008/.

Kalberer, M., Sax, M., and Samburova, V.: Molecular size evolution of oligomers in organic aerosols collected in urban atmospheres and generated in a smog chamber, Environ. Sci. Technol., 40, 5917-5922, 2006.

Kamens, R. M. and Jaoui, M.: Modelling aerosol formation from $\alpha$-pinene $+\mathrm{NO}_{\mathrm{x}}$ in the presence of natural sunlight using gasphase kinetics and gas-particle partitioning theory, Environ. Sci. Technol., 35, 1394-1405, 2001.

Kanakidou, M., Seinfeld, J. H., Pandis, S. N., Barnes, I., Dentener, F. J., Facchini, M. C., Van Dingenen, R., Ervens, B., Nenes, A., Nielsen, C. J., Swietlicki, E., Putaud, J. P., Balkanski, Y., Fuzzi, S., Horth, J., Moortgat, G. K., Winterhalter, R., Myhre, C. E. L., Tsigaridis, K., Vignati, E., Stephanou, E. G., and Wilson, J.: Organic aerosol and global climate modelling: a review, Atmos. Chem. Phys., 5, 1053-1123, 2005,

http://www.atmos-chem-phys.net/5/1053/2005/.

Karl, M., Brauers, T., Dorn, H.-P., Holland, F., Komenda, M., Poppe, D., Rohrer, F., Rupp, L., Schaub, A., and Wahner, A.: Kinetic study of the $\mathrm{OH}$-isoprene and $\mathrm{O}_{3}$-isoprene reaction in the atmosphere simulation chamber, SAPHIR, Geophys. Res. Lett., 31, L05117, doi:10.1029/2003GL019189, 2004.

Karl, M., Dorn, H.-P., Holland, F., Koppmann, R., Poppe, D., Rupp, L., Schaub, A., and Wahner, A.: Product study of the reaction of $\mathrm{OH}$ radicals with isoprene in the atmosphere simulation chamber SAPHIR, J. Atmos. Chem., 55, 167-187, doi:10.1007/s10874-006-9034-x, 2006.

Karl, M., Guenther, A., Köble, R., Leip, A., and Seufert, G.: A new European plant-specific emission inventory of biogenic volatile organic compounds for use in atmospheric transport models, Biogeosciences, 6, 1059-1087, 2009,

http://www.biogeosciences.net/6/1059/2009/.

Kleindienst, T. E., Jaoui, M., Lewandowski, M., Offenberg, J. H., Lewis, C. W., Bhave, P. V., and Edney, E. O.: Secondary organic carbon and aerosol yields from the irradiations of isoprene and $\alpha$-pinene in the presence of $\mathrm{NO}_{\mathrm{x}}$ and $\mathrm{SO}_{2}$ Environ. Sci. Technol., 40, 3807-3812, 2006

Kleindienst, T. E., Lewandowski, M., Offenberg, J. H., Jaoui, M., and Edney, E. O.: Ozone-isoprene reaction: Re-examination of the formation of secondary organic aerosol, Geophys. Res. Lett., 34, L01805, doi:10.1029/2006GL027485, 2007a.

Kleindienst, T. E., Jaoui, M., Lewandowski, M., Offenberg, J. H., Lewis, C. W., Bhave, P. V., and Edney, E. O.: Estimates of the contributions of biogenic and anthropogenic hydrocarbons to secondary organic aerosol at a southeastern US location, Atmos.
Environ., 41, 8288-8300, 2007b.

Koulouri, E., Saarikoski, S., Theodosi, C., Markaki, Z., Gerasopoulos, E., Kouvarakis, G., Mäkelä, T., Hillamo, R., and Mihalopoulos, N.: Chemical composition and sources of fine and coarse aerosol particles in the Eastern Mediterranean, Atmos. Environ. 42, 6542-6550, 2008.

Kourtchev, I., Ruuskanen, T., Maenhaut, W., Kulmala, M., and Claeys, M.: Observation of 2-methyltetrols and related photooxidation products of isoprene in boreal forest aerosols from Hyytiälä, Finland, Atmos. Chem. Phys., 5, 2761-2770, 2005, http://www.atmos-chem-phys.net/5/2761/2005/.

Krol, M., Houweling, S., Bregman, B., van den Broek, M., Segers, A., van Velthoven, P., Peters, W., Dentener, F., and Bergamaschi, P.: The two-way nested global chemistry-transport zoom model TM5: algorithm and applications, Atmos. Chem. Phys., 5, 417432, 2005, http://www.atmos-chem-phys.net/5/417/2005/.

Kroll, J. H. and Seinfeld, J. H.: Chemistry of secondary organic aerosol: Formation and evolution of low-volatility organics in the atmosphere, Atmos. Environ., 42, 3593-3624, 2008.

Kroll, J. H., Ng N. L, Murphy, S. M., Flagan, R. C., and Seinfeld, J. H.: Secondary organic aerosol from isoprene photooxidation under high- $\mathrm{NO}_{\mathrm{x}}$ conditions, Geophys. Res. Lett., 32, L18808, doi:10.1029/2005GL023637, 2005

Kroll, J. H., Ng N. L, Murphy, S. M., Flagan, R. C., and Seinfeld, J. H.: Secondary organic aerosol from isoprene photooxidation, Environ. Sci. Technol., 40, 1869-1877, 2006.

Kroll, J. H., Chan, A. W. H., Ng, N. L., Flagan, R. C., and Seinfeld, J. H.: Reactions of semivolatile organics and their effects on secondary organic aerosol formation, Environ. Sci. Technol., 41, 3545-3550, 2007.

Kupiainen, K. and Klimont, Z.: Primary emissions of fine carbonaceous particles in Europe, Atmos. Environ., 41, 2156-2170, 2007.

Lathière, J., Hauglustaine, D. A., De Noblet-Ducoudre, N., Krinner, G., and Folberth, G. A.: Past and future changes in biogenic volatile organic compound emissions simulated with a global dynamic vegetation model, Geophys. Res. Lett., 32, L20818, doi:10.1029/2005GL024164, 2005.

Liao, H., Henze, D. K., Seinfeld, J. H., Wu, S., and Mickley, L. J.: Biogenic secondary organic aerosol over the United States: Comparison of climatological simulations with observations, J. Geophys. Res., 112, D06201, doi:10.1029/2006JD007813, 2007.

Liggio, J., Li, S.-M., Brook, J. R., and Mihele, C.: Direct polymerization of isoprene and $\alpha$-pinene on acidic aerosols, Geophys. Res. Lett., 34, L05814, doi:10.1029/2006GL028468, 2007.

Lim, H.-J., Carlton, A. G., and Turpin, B. J.: Isoprene forms secondary organic aerosol through cloud processing: model simulations, Environ. Sci. Technol., 39, 4441-4446, 2005.

Limbeck, A., Kulmala, M., and Puxbaum, H.: Secondary organic aerosol formation in the atmosphere via heterogeneous reaction of gaseous isoprene on acidic particles, Geophys. Res. Lett., 30(19), 1996, doi:10.1029/2003GL017738, 2003.

Louis, J. F.: A parametric model of vertical eddy fluxes in the atmosphere, Bound.-Lay. Meteorol., 17, 187-202, 1979.

Marmer, E. and Langmann, B.: Aerosol modeling over Europe: 1. Interannual variability of aerosol distribution, J. Geophys. Res., 112(D23), D23S15, doi:10.1029/2006JD008113, 2007. 
Matsunaga, S. N., Wiedinmyer, C., Guenther, A. B., Orlando, J. J., Karl, T., Toohey, D. W., Greenberg, J. P., and Kajii, Y.: Isoprene oxidation products are a significant atmospheric aerosol component, Atmos. Chem. Phys. Discuss., 5, 11143-11156, 2005, http://www.atmos-chem-phys-discuss.net/5/11143/2005/.

Mayol-Bracero, O. L., Guyon, P., Graham, B., Roberts, G., Andreae, M. O., Decesari, S., Facchini, M. C., Fuzzi, S., and Artaxo, P.: Water-soluble organic compounds in biomass burning aerosols over Amazonia, 2. Apportionment of the chemical composition and importance of the polyacidic fraction, J. Geophys. Res., 107(D20), 8091, doi:10.1029/2001JD000522, 2002.

Metzger, S. M., Dentener, F. J., Lelieveld, J., and Pandis, S. N.: Gas/aerosol partitioning: 1. A computationally efficient model, J. Geophys. Res., 107(D16), 4312, doi:10.1029/2001JD001102, 2002a.

Metzger, S. M., Dentener, F. J., Jeuken, A., Krol, M., and Lelieveld, J.: Gas/aerosol partitioning: 2. Global modeling results, J. Geophys. Res., 107(D16), 4313, doi:10.1029/2001JD001103, 2002b.

Myriokefalitakis, S., Vrekoussis, M., Tsigaridis, K., Wittrock, F., Richter, A., Brühl, C., Volkamer, R., Burrows, J. P., and Kanakidou, M.: The influence of natural and anthropogenic secondary sources on the glyoxal global distribution, Atmos. Chem. Phys., 8, 4965-4981, 2008,

http://www.atmos-chem-phys.net/8/4965/2008/.

Müller, J.-F., Stavrakou, T., Wallens, S., De Smedt, I., Van Roozendael, M., Potosnak, M. J., Rinne, J., Munger, B., Goldstein, A., and Guenther, A. B.: Global isoprene emissions estimated using MEGAN, ECMWF analyses and a detailed canopy environment model, Atmos. Chem. Phys., 8, 1329-1341, 2008,

http://www.atmos-chem-phys.net/8/1329/2008/.

Ng, L. N., Kroll, J. H., Keywood, M. D., Bahreini, R., Varutbangkul, V., Flagan, R. C., Seinfeld, J. H., Lee, A., and Goldstein, A. H.: Contribution of first- versus second-generation products to secondary organic aerosols formed in the oxidation of biogenic hydrocarbons, Environ. Sci. Technol., 40, 2283-2297, 2006.

Odum, J. R., Hoffmann, T., Bowman, F., Collins, D., Flagan, R. C., and Seinfeld, J. H.: Gas/particle partitioning and secondary organic aerosol yields, Environ. Sci. Technol., 30, 2580-2585, 1996.

Odum, J. R., Jungkamp, T. P. W., Griffin, R. J., Flagan, R. C., and Seinfeld, J. H.: The atmospheric aerosol-forming potential of whole gasoline vapor, Science, 276, 96-99, 1997.

Offenberg, J. H., Kleindienst, T. E., Jaoui, M., Lewandowski, M., and Edney, E. O.: Thermal properties of secondary organic aerosols, Geophys. Res. Lett., 33, L03816, doi:10.1029/2005GL024623, 2006.

Olivier, J., Bouwman, A. F., Van der Maas, C. W. M., Berdowski, J. J. M., Veldt, C., Bloos, J. P. J., Visschedijk, A. J. H., Zandveld, P. Y. J., and Haverlag, J. L.: Description of EDGAR Version 2.0: a set of emission inventories of greenhouse gases and ozone depleting substances for all anthropogenic and most natural sources on a per country basis and on $1^{\circ} \times 1^{\circ}$ grid, RIVM Report nr. 771060002 and TNO-MEP Report nr. R96/119, 1996.

Olson, J.: World ecosystems (WE1.4): Digital raster data on a 10 minute geographic $1080 \times 2160$ grid, in: Global Ecosystems Database, Version 1.0: Disc A, Natl. Geophys. Data Cent., Natl.
Oceanic and Atmos. Admin., Boulder, Colorado, 1992.

Pandis, S. N., Paulson, S. E., Seinfeld, J. H., and Flagan, R. C.: Aerosol formation in the photooxidation of isoprene and $\beta$ pinene, Atmos. Environ., 25A, 997-1008, 1991.

Pankow, J.: An absorption model of gas/particle partitioning of organic compounds in the atmosphere, Atmos. Environ., 28, 185188, 1994a.

Pankow, J.: An absorption model of the gas/aerosol partitioning involved in the formation of secondary organic aerosol. Atmos. Environ., 28, 189-193, 1994b.

Pankow, J. F. and Barsanti, K. C.: The carbon number-polarity grid: A means to manage the complexity of the mix of organic compounds when modeling atmospheric organic particulate matter, Atmos. Environ., 43, 2829-2835, 2009.

Pathak, R. K., Presto, A. A., Lane, T. E., Stanier, C. O., Donahue, N. M., and Pandis, S. N.: Ozonolysis of $\alpha$-pinene: parameterization of secondary organic aerosol mass fraction, Atmos. Chem. Phys., 7, 3811-3821, 2007, http://www.atmos-chem-phys.net/7/3811/2007/.

Peters, W., Krol, M. C., Dlugokencky, E. J., Dentener, F. J., Bergamaschi, P., Dutton, G., v. Velthoven, P., Miller, J. B., Bruhwiler, L., and Tans, P. P.: Toward regional-scale modeling using the two-way nested global model TM5: Characterization of transport using $\mathrm{SF}_{6}$, J. Geophys, Res., 109, D19314, doi:10.1029/2004JD005020, 2004.

PHOENICS, Synthesis and Integration Report, edited by: M. Kanakidou, and F. J. Dentener, Particles of human origin extinguish natural solar irradiance in the climate system EVK2-CT2001-00098, ISBN:960-88712-0-4, Emedia University of Crete, Heraklion, Greece. http://phoenics.chemistry.uoc.gr, 2005.

Presto, A. A. and Donahue, N. M.: Investigation of $\alpha$-Pinene + ozone secondary organic aerosol formation at low total aerosol mass, Environ. Sci. Technol., 40, 3536-3543, 2006.

Presto, A. A., Huff Hartz, K. E., and Donahue, N. M.: Secondary organic aerosol production from terpene ozonolysis. 1. Effect of UV radiation, Environ. Sci. Technol., 39(18), 7036-7045, $2005 \mathrm{a}$.

Presto, A. A., Huff Hartz, K. E., and Donahue, N. M.: Secondary organic aerosol production from terpene ozonolysis. 2. Effect of $\mathrm{NO}_{\mathrm{x}}$ concentration, Environ. Sci. Technol., 39(18), 7046-7054, $2005 b$.

Pun, B. K. and Seigneur, C.: Investigative modeling of new pathways for secondary organic aerosol formation, Atmos. Chem. Phys., 7, 2199-2216, 2007,

http://www.atmos-chem-phys.net/7/2199/2007/.

Pun, B. K., Griffin, R. J., Seigneur, C., and Seinfeld, J. H.: Secondary organic aerosol: II. Thermodynamic model for gas/particle partitioning of molecular constituents, J. Geophys. Res., 107(D17), 4333, doi:10.1029/2001JD000542, 2002.

Pun, B. K., Wu, S. Y., Seigneur, C., Seinfeld, J. H., Griffin, R. J., and Pandis, S. N.: Uncertainties in modelling secondary organic aerosols: Three-dimensional modelling studies in Nashville/West Tennessee, Environ. Sci. Technol., 37, 36473661, 2003.

Robinson, A. L., Donahue, N. M., Shrivastava, M. K., Weitkamp, E. A:, Sage, A. M., Grieshop, A. P., Lane, T. E., Pierce, J. R., and Pandis, S. N.: Rethinking organic aerosols: semivolatile emissions and photochemical aging, Science, 315, 1259-1262, 2007.

Russel, G. and Lerner, J.: A new finite-differencing scheme for the tracer transport equation, J. Appl. Meteorol., 20, 1483-1498, 
1981.

Sakulyanontvittaya, T., Duhl, T., Wiedinmyer, C., Helmig, D., Matsunaga, S., Potosnak, M., Milford, J., and Guenther, A.: Monoterpene and sesquiterpene emission estimates for the United States, Environ. Sci. Technol., 42(5), 1623-1629, 2008.

Sander, R.: Compilation of Henry's law constants for inorganic and organic species of potential importance in environmental chemistry (version 3), Max-Planck Inst. of Chem., Mainz, Germany. Available at http://www.mpch-mainz.mpg.de/ $\sim$ sander/res/henry. html, 1999.

Saunders, S. M., Jenkin, M. E., Derwent, R. G., and Pilling, M. J.: Protocol for the development of the Master Chemical Mechanism, MCM v3 (Part A): tropospheric degradation of nonaromatic volatile organic compounds, Atmos. Chem. Phys., 3, 161-180, 2003, http://www.atmos-chem-phys.net/3/161/2003/.

Seinfeld, J. H. and Pankow, J. F.: Organic atmospheric particulate material, Annu. Rev. Phys. Chem., 54, 121-140, 2003.

Simpson, D., Winiwarter, W., Börjesson, G., Cinderby, S., Ferreiro, A., Guenther, A., Hewitt, N., Janson, R., Khalil, M. A. K., Owen, S., Pierce, T. E., Puxbaum, H., Shearer, M., Skiba, U., Steinbrecher, R., Tarrasón, L., and Öquist, M. G.: Inventorying emissions from nature in Europe, J. Geophys. Res., 104(D7), 8113-8152, 1999.

Simpson, D., Yttri, K. E., Klimont, Z., Kupiainen, K., Caseiro, A., Gelencsér, A., Pio, C., Puxbaum, H., and Legrand, M.: Modeling carbonaceous aerosol over Europe: Analysis of the CARBOSOL and EMEP EC/OC campaign, J. Geophys. Res., 112, D23S14, doi:10.1029/2006JD008158, 2007.

Song, C., Na, K., and Cocker III, D. R.: Impact of the hydrocarbon to $\mathrm{NO}_{\mathrm{x}}$ ratio on secondary organic aerosol formation, Environ. Sci. Technol., 39, 3143-3149, 2005.

Spittler, M., Barnes, I., Bejana, I., Brockmann, K. J., Benter, Th., and Wirtz, K.: Reactions of $\mathrm{NO}_{3}$ radicals with limonene and $\alpha$ pinene: Product and SOA formation, Atmos. Environ., 40, S116S127, 2006.

Steinbrecher, R., Smiatek, G., Köble, R., Seufert, G., Theloke, J., Hauff, K., Ciccioli, P., Vautard, R., and Curci, G.: Intra- and inter-annual variability of VOC emissions from natural and seminatural vegetation in Europe and neighbouring countries, Atmos. Environ., 43(7), 1380-1391, 2009.

Surratt, J. D., Murphy, S. M., Kroll, J. H., Ng, N. L., Hildebrandt, L., Sorooshian, A., Szmigielski, R., Vermeylen, R., Maenhaut, W., Claeys, M., Flagan, R. C., and Seinfeld, J. H.: Chemical composition of secondary organic aerosol formed from the photooxidation of isoprene, J. Phys. Chem. A, 110, 9665-9690, 2006.

Surratt, J. D., Kroll, J. H., Kleindienst, T. E., Edney, E. O., Claeys, M., Sorooshian, A., Ng, N. L., Offenberg, J. H., Lewandowski, M., Jaoui, M., Flagan, R. C., and Seinfeld, J. H.: Evidence of organosulfates in secondary organic aerosol, Environ. Sci. Technol., 41, 517-527, 2007a.

Surratt, J. D., Lewandowski, M., Offenberg, J. H., Jaoui, M., Kleindienst, T. E., Edney, E. O., and Seinfeld, J. H.: Effect of acidity on secondary organic aerosol formation from isoprene, Environ. Sci. Technol., 41, 5363-5369, 2007b.

Textor, C., Schulz, M., Guibert, S., Kinne, S., Balkanski, Y., Bauer, S., Berntsen, T., Berglen, T., Boucher, O., Chin, M., Dentener, F., Diehl, T., Easter, R., Feichter, H., Fillmore, D., Ghan, S., Gi- noux, P., Gong, S., Grini, A., Hendricks, J., Horowitz, L., Huang, P., Isaksen, I., Iversen, I., Kloster, S., Koch, D., Kirkevåg, A., Kristjansson, J. E., Krol, M., Lauer, A., Lamarque, J. F., Liu, X., Montanaro, V., Myhre, G., Penner, J., Pitari, G., Reddy, S., Seland, Ø., Stier, P., Takemura, T., and Tie, X.: Analysis and quantification of the diversities of aerosol life cycles within AeroCom, Atmos. Chem. Phys., 6, 1777-1813, 2006,

http://www.atmos-chem-phys.net/6/1777/2006/.

Tiedtke, M.: A comprehensive mass flux scheme for cumulus parameterisation in large scale models, Mon. Weather Rev., 177, 1779-1800, 1989.

Tilgner, A., Wolke, R., and Herrmann, H.: CAPRAM modelling of the physicochemical cloud processing of tropospheric aerosols, in Environmental simulation chambers - Application to atmospheric chemical processes. Proceedings of the NATO Advanced Research Workshop on Simulation and Assessment of Chemical Processes in a Multiphase Environment Alushta, Ukraine 1 September 2007, edited by: I. Barnes and M. Kharytonov, p. 540, Springer, Berlin; Heidelberg ; New York, 2008.

Tingey, D. T., Turner, D. P., and Weber, J. A.: Factors controlling the emissions of monoterpenes and other volatile organic compounds, in: Trace Gas Emissions by Plants, edited by: Sharkey, T. D., Holland, E. A., and Mooney, H. A., Academic Press, New York, pp. 93-119, 1991.

Tsigaridis, K. and Kanakidou, M.: Global modelling of secondary organic aerosol in the troposphere: a sensitivity analysis, Atmos. Chem. Phys., 3, 1849-1869, 2003, http://www.atmos-chem-phys.net/3/1849/2003/.

Tsigaridis, K. and Kanakidou, M.: Secondary organic aerosol importance in the future atmosphere, Atmos. Environ., 41, 46824692, 2007.

Tsigaridis, K., Krol, M., Dentener, F. J., Balkanski, Y., Lathière, J., Metzger, S., Hauglustaine, D. A., and Kanakidou, M.: Change in global aerosol composition since preindustrial times, Atmos. Chem. Phys., 6, 5143-5162, 2006, http://www.atmos-chem-phys.net/6/5143/2006/.

US EPA, Environmental Protection Agency: Air Emission Sources, http://www.epa.gov/air/emissions/voc.htm, 2008.

van der Werf, G. R., Randerson, J. T., Collatz, G. J., and Giglio, L.: Continental-Scale partitioning of fire emissions during the 1997 to $2001 \mathrm{El} \mathrm{Niño/La} \mathrm{Niña} \mathrm{period,} \mathrm{Science,} \mathrm{303,} \mathrm{73-76,} 2004$ Database available online at: http://www.ess.uci.edu/ jranders/ van Donkelaar, A., Martin, R. V., Park, R. J., Heald, C. L., Fu, T.M., Liao, H., and Guenther, A.: Model evidence for a significant source of secondary organic aerosol from isoprene, Atmos. Environ., 41(6), 1267-1274, 2007.

Vignati, E., Krol, M., and Dentener, F.: Global and regional aerosol modelling: A picture over Europe, in: Advances in Air Pollution Modeling for Environmental Security, edited by: Faragó, I., et al., ISBN: 978-1-4020-3350-6, 406 pp., NATO Science Series: IV: Earth and Environmental Sciences, Vol. 54, Springer, The Netherlands, 373-381, 2005.

Weiss, A. and Norman, J. M.: Partitioning solar radiation into direct and diffuse, visible and near-infrared components. Agr. Forest. Meteorol., 34, 205-213, 1985.

Wiedinmyer, C., Guenther, A., Harley, P., Hewitt, N., Geron, C., Artaxo, P., Steinbrecher, R., and Rasmussen, R.: Global Organic Emissions from Vegetation, in: Emissions of Atmospheric Trace Compounds, edited by: Granier, C., Artaxo, P., and Reeves, C., 
544 pp., Kluwer Academic Publishers, Dordrecht, The Netherlands, 115-170, 2004.

Yttri, K. E., Aas, W., Bjerke, A., Cape, J. N., Cavalli, F., Ceburnis, D., Dye, C., Emblico, L., Facchini, M. C., Forster, C., Hanssen, J. E., Hansson, H. C., Jennings, S. G., Maenhaut, W., Putaud, J. P., and Tørseth, K.: Elemental and organic carbon in $\mathrm{PM}_{10}$ : a one year measurement campaign within the European Monitoring and Evaluation Programme EMEP, Atmos. Chem. Phys., 7, 5711-5725, 2007,

http://www.atmos-chem-phys.net/7/5711/2007/. 